\title{
Global carbonyl sulfide (OCS) measured by MIPAS/Envisat during 2002-2012
}

\author{
Norbert Glatthor $^{1}$, Michael Höpfner ${ }^{1}$, Adrian Leyser ${ }^{1, a}$, Gabriele P. Stiller ${ }^{1}$, Thomas von Clarmann ${ }^{1}$, \\ Udo Grabowski $^{1}$, Sylvia Kellmann ${ }^{1}$, Andrea Linden ${ }^{1}$, Björn-Martin Sinnhuber ${ }^{1}$, Gisèle Krysztofiak ${ }^{2}$, and \\ Kaley A. Walker ${ }^{3}$ \\ ${ }^{1}$ Karlsruher Institut für Technologie, Institut für Meteorologie und Klimaforschung, Karlsruhe, Germany \\ ${ }^{2}$ University of Orléans, LPC2E, CNRS, Orléans, France \\ ${ }^{3}$ Department of Physics, University of Toronto, Toronto, Canada \\ ${ }^{a}$ now at: Deutscher Wetterdienst, Abteilung Basisvorhersagen, Offenbach, Germany \\ Correspondence to: Norbert Glatthor (norbert.glatthor@kit.edu)
}

Received: 5 August 2016 - Discussion started: 13 September 2016

Revised: 23 December 2016 - Accepted: 12 January 2017 - Published: 21 February 2017

\begin{abstract}
We present a global carbonyl sulfide (OCS) data set covering the period June 2002 to April 2012, derived from FTIR (Fourier transform infrared) limb emission spectra measured with the Michelson Interferometer for Passive Atmospheric Sounding (MIPAS) on the ENVISAT satellite. The vertical resolution is $4-5 \mathrm{~km}$ in the height region $6-15 \mathrm{~km}$ and 15 at $40 \mathrm{~km}$ altitude. The total estimated error amounts to $40-50 \mathrm{pptv}$ between 10 and $20 \mathrm{~km}$ and to $120 \mathrm{pptv}$ at $40 \mathrm{~km}$ altitude. MIPAS OCS data show no systematic bias with respect to balloon observations, with deviations mostly below \pm 50 pptv. However, they are systematically higher than the OCS volume mixing ratios of the ACE-FTS instrument on SCISAT, with maximum deviations of up to $100 \mathrm{pptv}$ in the altitude region $13-16 \mathrm{~km}$. The data set of MIPAS OCS exhibits only moderate interannual variations and low interhemispheric differences. Average concentrations at $10 \mathrm{~km}$ altitude range from $480 \mathrm{pptv}$ at high latitudes to 500-510 pptv in the tropics and at northern midlatitudes. Seasonal variations at $10 \mathrm{~km}$ altitude amount to up to $35 \mathrm{pptv}$ in the Northern and up to $15 \mathrm{pptv}$ in the Southern Hemisphere. Northern hemispheric OCS abundances at $10 \mathrm{~km}$ altitude peak in June in the tropics and around October at high latitudes, while the respective southern hemispheric maxima were observed in July and in November. Global OCS distributions at $250 \mathrm{hPa}(\sim 10-11 \mathrm{~km})$ show enhanced values at low latitudes, peaking during boreal summer above the western Pacific and the Indian Ocean, which indicates oceanic release. Further, a region of depleted OCS amounts
\end{abstract}

extending from Brazil to central and southern Africa was detected at this altitude, which is most pronounced in austral summer. This depletion is related to seasonally varying vegetative uptake by the tropical forests. Typical signatures of biomass burning like the southern hemispheric biomass burning plume are not visible in MIPAS data, indicating that this process is only a minor source of upper tropospheric OCS. At the $150 \mathrm{hPa}$ level $(\sim 13-14 \mathrm{~km})$ enhanced amounts of OCS were also observed inside the Asian monsoon anticyclone, but this enhancement is not especially outstanding compared to other low latitude regions at the same altitude. At the $80 \mathrm{hPa}$ level $(\sim 17-18 \mathrm{~km})$, equatorward transport of midlatitude air masses containing lower OCS amounts around the summertime anticyclones was observed. A significant trend could not be detected in upper tropospheric MIPAS OCS amounts, which points to globally balanced sources and sinks. Simulations with the ECHAM-MESSy model reproduce the observed latitudinal cross sections fairly well.

\section{Introduction}

The first measurements of atmospheric carbonyl sulfide (OCS), which is the most prevalent sulfur-containing trace gas, were performed by Hanst et al. (1975) and Sandalls and Penkett (1977). Its relative long tropospheric lifetime of 3 4 years (Chin and Davis, 1993; Griffith et al., 1998) favours its enrichment in the troposphere and enables its ascent into 
the stratosphere, where during volcanically unperturbed periods it acts as dominant source of sulfur as prerequisite of the stratospheric aerosol layer (Crutzen, 1976; Kremser et al., 2016). Since stratospheric aerosols have a significant contribution to climate forcing, good knowledge of sources, sinks and fluxes of atmospheric sulfur is of scientific interest. Anthropogenic sources of atmospheric sulfur can be quantified rather accurately, but the characteristics of the natural sulfur cycle are still not sufficiently well known. One reason is the lack of widespread measurements of OCS to better constrain our knowledge on its sources and sinks. In this respect the comprehensive data set of MIPAS can give further insight on the global OCS distribution.

Various scientific studies have been performed to quantify natural and anthropogenic sulfur emissions and sinks (Eriksson, 1960; Junge, 1963; Robinson and Robbins, 1968; Kel$\operatorname{logg}$ et al., 1972; Friend, 1973; Adams et al., 1981; Andreae, 1990; Chin and Davis, 1993; Kuhn et al., 1999). These authors reported strongly differing values, reflecting large uncertainties in determination of sulfur fluxes. More recent estimates of the OCS budget were given by Watts (2000) and Kettle et al. (2002). In these estimates the oceans are generally assumed to be the dominant source and vegetative uptake to be the dominant sink.

While in earlier estimates the OCS budget often was unbalanced, sources and sinks are better balanced in Kettle et al. (2002). The direct flux of OCS from the oceans as well as indirect release via outgassing of dimethyl sulfide (DMS) and subsequent oxidization into OCS is highest at mid-latitudes during spring and summer. Indirect oceanic release via outgassing of carbon disulfide $\left(\mathrm{CS}_{2}\right)$ occurs at low latitudes and maximizes during local summer. Vegetative uptake is largest during plant growth in summer and is much stronger in the Northern Hemisphere, where the global land masses are concentrated. According to subsequent assessments by Xu et al. (2002), Sandoval-Soto et al. (2005), Montzka et al. (2007), Suntharalingam et al. (2008) and Berry et al. (2013), vegetative uptake might be up to 3-6 times higher than estimated in Kettle et al. (2002). A comprehensive compilation of these budget estimations is given in Kremser et al. (2016).

In most budget estimations, biomass burning has not been considered as a major source of atmospheric OCS (Chin and Davis, 1993; Nguyen et al., 1995; Watts, 2000; Kettle et al., 2002; Montzka et al., 2007; Suntharalingam et al., 2008; Berry et al., 2013). Nguyen et al. (1995) give an estimate of $10 \%$ for the contribution of biomass burning to the global OCS emissions, and the contribution of biomass burning in Berry et al. (2013) is about $13 \%$. However, Notholt et al. (2003) measured extraordinarily enhanced OCS amounts of up to 600 pptv on two ship cruises (October-November 1996, December-January 1999/2000) in the height region $10-18 \mathrm{~km}$ above the tropical and subtropical Atlantic, which they attributed to biomass burning. Further, Barkley et al. (2008) presented ACE-FTS observa- tions of enhanced OCS at $10-15 \mathrm{~km}$ between the Equator and $30^{\circ} \mathrm{S}$ during boreal fall, which they assigned to biomass burning as well.

Another topic of scientific interest is the question of whether there is a trend in atmospheric OCS or if the budget is balanced. A positive trend would potentially lead to an increase of the stratospheric aerosol layer and thus cause a negative climate forcing. However, since OCS itself is a strong greenhouse gas, the net climate forcing of an OCS trend would likely be very small (Brühl et al., 2012). For the period 1978-2002, Rinsland et al. (2002) calculated a weak decrease of $(-2.5 \pm 0.4) \%$ decade $^{-1}$ for the altitude range of $2-10 \mathrm{~km}$ above Kitt Peak $\left(31.9^{\circ} \mathrm{N}, 111.6^{\circ} \mathrm{W}\right)$. Mahieu et al. (2005) reported a decrease of about $7 \%$ of the total OCS column above the Jungfraujoch $\left(46.5^{\circ} \mathrm{N}\right.$, 8.0 $0^{\circ}$ E) obtained between 1988 and 2001, and an increase during the subsequent 3 years. Both time series were obtained using ground-based Fourier transform infrared (FTIR) spectroscopy. For the tropospheric OCS column above the Jungfraujoch, Lejeune et al. (2017) determined a negative trend of $(-8.9 \pm 0.8) \%$ decade $^{-1}$ for the period 1995-2002, a positive trend of $(13.4 \pm 0.8) \%$ decade $^{-1}$ during the years 2002-2008 and no significant trend for the years 2008-2015. According to these authors these trends are mainly driven by tropospheric processes, because for stratospheric OCS they found a weak trend of $(2.0 \pm 0.6) \%$ decade $^{-1}$ over the whole period 1995-2015 only. In another investigation of groundbased FTIR measurements at three stations between 34.45 and $77.80^{\circ} \mathrm{S}$, Kremser et al. (2015) determined positive trends in total column OCS between $(4.3 \pm 0.2) \%$ decade $^{-1}$ and $(7.3 \pm 0.3) \%$ decade $^{-1}$ for the time period 2001-2014 and concluded that the OCS budget is not closed. In a long time series of firn air collected near the South Pole, Montzka et al. (2004) found a significant increase from the mid-1800s to the late 1900s, but a considerable decrease of $10-16 \%$ between the mid-1980s and the turn of the millennium. From the analysis of flask data obtained between 2000 and 2005 at the ground-based stations of the global network of the Earth System Research Laboratory of the National Oceanic and Atmospheric Administration (NOAA ESRL), Montzka et al. (2007) did not find a significant trend in tropospheric OCS.

Long time series of OCS are available from a few locations only. Ground-based FTIR measurements at the Jungfraujoch in Switzerland started in the mid-1980s (Mahieu et al., 2005). Balloon-borne observations by the MkIV FTIR spectrometer of the Jet Propulsion Laboratory (Toon, 1991) have been performed since 1989, with 23 launches mainly from Fort Sumner (New Mexico), Esrange (Sweden), and Fairbanks (Alaska). Since the year 2000, NOAA ESRL has performed flask measurements of OCS on a global network of about a dozen stations (Montzka et al., 2007). NOAA ESRL data are available at http://www.esrl.noaa.gov/gmd/hats/gases/OCS. $\mathrm{html}$. A compilation of the latitudinal OCS distribution obtained by different measurement techniques (ground-based 
in situ and FTIR, balloon-borne FTIR, aircraft and ship measurements) has been presented by Krysztofiak et al. (2014). The first spaceborne OCS measurements were performed with the ATMOS interferometer on the space-shuttle (Farmer et al., 1987). A global spaceborne data set of OCS was derived from MIPAS measurements by Burgess et al. (2004) for a restricted time period. Barkley et al. (2008) presented upper tropospheric and stratospheric global OCS distributions of the time period 2004-2006 from spaceborne measurements of the Fourier Transform Spectrometer of the Atmospheric Chemistry Experiment (ACE-FTS) on the Canadian SCISAT satellite (Bernath et al., 2005; Boone et al., 2005). Spaceborne OCS measurements of the NASA Aura Tropospheric Emission Spectrometer (TES) and of the Infrared Atmospheric Sounding Interferometer (IASI) have been presented by Kuai et al. (2014) and by Vincent and Dudhia (2016), respectively.

The MIPAS OCS data set has already been presented in Glatthor et al. (2015a), but focused on the signatures of tropical sources and sinks at the $250 \mathrm{hPa}$ level only. In this paper we will give a more global overview of this data set. We will describe the MIPAS instrument, the OCS retrieval setup and the validation of the MIPAS OCS data. Then we will present time series of the OCS data set at different height levels and discuss latitudinal cross sections as well as seasonal variations. Horizontal distributions at different upper tropospheric pressure levels will indicate source and sink regions of OCS. The contributions of oceanic release and of uptake by tropical vegetation, which have already been presented in Glatthor et al. (2015a), will only be briefly discussed. Instead we will investigate the impact of biomass burning and meridional transport patterns visible in the tropopause region. Further, we will perform a dedicated analysis of the decennial trend.

\section{MIPAS measurements}

\subsection{Instrument description}

On 1 March 2002, the Environmental Satellite (ENVISAT) was launched into a Sun-synchronous polar orbit at about $800 \mathrm{~km}$ altitude. Among various other experiments the satellite contained the Michelson Interferometer for Passive Atmospheric Sounding (MIPAS). MIPAS is a limb-viewing FTIR emission spectrometer covering the mid-infrared spectral region between 685 and $2410 \mathrm{~cm}^{-1}(4.1-14.6 \mu \mathrm{m})$, which enables simultaneous observation of numerous trace gases (European Space Agency (ESA), 2000; Fischer et al., 2008). MIPAS data are available from June 2002 until April 2012, when the communication to ENVISAT was lost. MIPAS has been operated in two different measurement modes, the original high-resolution (HR) mode from June 2002 to April 2004 and in the reduced resolution (RR) mode since January 2005. This change of the measurement mode was due to technical problems and resulted in a reduction of the spectral resolution from 0.025 to $0.0625 \mathrm{~cm}^{-1}$. On the other hand, this change led to reduction of the latitudinal sampling distance from about 530 to $400 \mathrm{~km}$ and to narrower vertical sampling.

We present data of the HR and of the RR "nominal" measurement modes as well as of the RR "UTLS" mode. The nominal modes consisted of rearward limb-scans covering the altitude region between 7 and $72 \mathrm{~km}$ within 17 and 27 altitude steps, respectively, and the UTLS mode of scans from about 5.5 to $49 \mathrm{~km}$ altitude. The vertical sampling of the HR mode was $3 \mathrm{~km}$ up to $42 \mathrm{~km}$ and 5 to $8 \mathrm{~km}$ at higher altitudes. The sampling of the RR nominal and UTLS modes was $1.5 \mathrm{~km}$ up to $22 \mathrm{~km}, 2 \mathrm{~km}$ up to $32 \mathrm{~km}, 3 \mathrm{~km}$ up to $44 \mathrm{~km}$ and $4-4.5 \mathrm{~km}$ for the upper part of the scan. MIPAS could be operated during day-time and night-time, and nominally produced 1000 and 1400 scans per day in HR and RR nominal mode, respectively. The level-1B radiance spectra used for retrieval are data version 5.02/5.06 (reprocessed data) provided by the ESA (Nett et al., 2002).

\subsection{Retrieval method and error estimation}

Retrievals were performed with the common processor of the Institut für Meteorologie und Klimaforschung and the Instituto de Astrofísica de Andalucía (IMK/IAA). This processor uses the Karlsruhe Optimized and Precise Radiative Algorithm (KOPRA) (Stiller, 2000) for radiative transfer calculations and the Retrieval Control Program (RCP) of IMK/IAA for inverse modelling. Processing of MIPAS data at IMK has been described in, e.g., von Clarmann et al. (2003) and Höpfner et al. (2004). The presented OCS distributions are the most recent data versions, i.e. V5H_OCS_20 of the MIPAS HR mode and V5R_OCS_221/222 as well as V5R_OCS_120 of the MIPAS RR mode.

The OCS retrieval at IMK is performed using 7 microwindows, which cover the spectral range $839-876 \mathrm{~cm}^{-1}$ of the fundamental $v_{1}$ band. To model the spectroscopic signature of OCS, line data of the 2009 update for OCS of the HITRAN 2008 database (Rothman et al., 2009) were applied. This update is consistent with the OCS spectroscopy in the HITRAN 2012 release (Rothman et al., 2013). The spectral line shape of the interfering gases $\mathrm{H}_{2} \mathrm{O}, \mathrm{CO}_{2}, \mathrm{O}_{3}$ and $\mathrm{NO}_{2}$ was modelled by means of the spectroscopy of the MIPAS database, version 3.2 (Flaud et al., 2003). For simulation of the signature of the remaining interfering gases, the spectroscopy of the HITRAN database was used. Figure 1 shows the OCS signatures in the spectral range 839$876 \mathrm{~cm}^{-1}$ for a MIPAS scan obtained on 12 July 2009 at southern mid-latitudes $\left(42.8^{\circ} \mathrm{S}, 18.7^{\circ} \mathrm{E}\right)$. The displayed radiances are the differences between model spectra resulting from the OCS retrieval and model spectra for the same, but OCS-free, atmosphere at tangent heights of $9.8 \mathrm{~km}$ (left) and $20.0 \mathrm{~km}$ (right). The red curves indicate the instrumental noise-equivalent spectral radiance (NESR). At $9.8 \mathrm{~km}$ alti- 

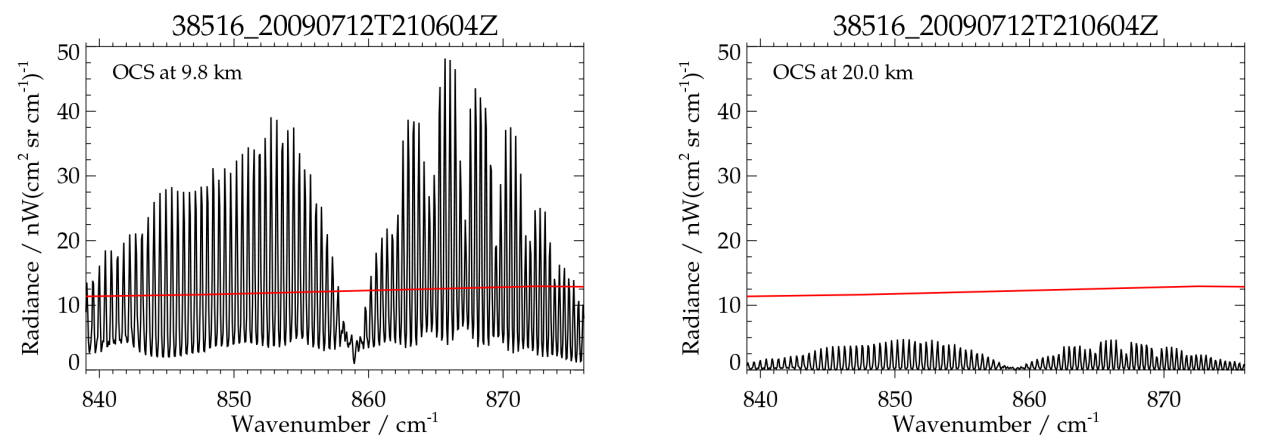

Figure 1. Left: spectral OCS signature for a measurement on 12 July 2009 at southern mid-latitudes $\left(42.8^{\circ} \mathrm{S}, 18.7^{\circ} \mathrm{E}\right)$ at $9.8 \mathrm{~km}$ tangent height, expressed as difference between the model spectrum resulting from the OCS fit and a spectrum for the same atmosphere without OCS. Right: same as left, but for $20.0 \mathrm{~km}$ altitude. Red curves indicate the noise-equivalent spectral radiance (NESR).

tude most of the OCS lines are a factor of 2-5 stronger than instrumental NESR, which indicates good retrievability of OCS. At $20.0 \mathrm{~km}$ the individual OCS lines are a factor of 2 or more weaker than instrumental NESR, but the effective signal-to-noise ratio is higher by a considerable factor, because there are dozens of OCS lines in this spectral window. Thus, retrieval of OCS at this altitude is also possible.

The inversion consists of derivation of vertical profiles of atmospheric state parameters from MIPAS level-1B spectra by constrained non-linear least-squares fitting in a globalfit approach (von Clarmann et al., 2003). Since the retrieval grid chosen has a finer altitude spacing than the height distance between the tangent altitudes, a constraint is necessary to attenuate instabilities. For this purpose, Tikhonov's first derivative operator was applied (Steck, 2002, and references therein). Instead of climatological OCS profiles, a heightconstant profile (zero at all altitudes) was chosen as a priori. Due to this particular choice of the regularization matrix, the fitted profile is a smoothed representation of the true profile, but the abundances are not pushed towards the a priori values. Along with OCS, the profiles of the main interfering trace gases $\mathrm{HNO}_{3}, \mathrm{CFC}-11$ and $\mathrm{O}_{3}$ were jointly fitted. Additional retrieval variables were microwindow-dependent continuum radiation profiles and microwindow-dependent, but heightindependent, zero-level calibration corrections. The radiative contribution of other interfering gases like $\mathrm{H}_{2} \mathrm{O}, \mathrm{ClO}, \mathrm{C}_{2} \mathrm{H}_{6}$ and $\mathrm{NO}_{2}$ was modelled by using their profiles retrieved earlier in the processing sequence. The contribution of interfering gases, which had not been prefitted, was modelled using the profiles of the climatology by Remedios et al. (2007).

MIPAS data provide information on atmospheric OCS from the lower end of the profiles in the free troposphere up to about $40 \mathrm{~km}$ altitude. To illustrate the performance of a single scan retrieval, Fig. 2 (top left) shows an OCS profile obtained on 12 July 2009 at the same geolocation as in Fig. 1, along with the measurement noise error. The profile exhibits OCS volume mixing ratios (VMRs) of 425-450 pptv in the troposphere and a strong decline in the stratosphere to values below $100 \mathrm{pptv}$ above $30 \mathrm{~km}$ altitude. For altitudes between 10 and $19 \mathrm{~km}$ the rows of the respective averaging kernels (AKs) are symmetrical to their middle value (Fig. 2, top right), which means that in this height region the OCS signal results from the nominal altitudes. The AK related to $7 \mathrm{~km}$ is centred at $8-9 \mathrm{~km}$, showing that the OCS signal is from 1 to $2 \mathrm{~km}$ above. In the stratosphere the AKs are centred at increasingly lower altitudes with a displacement of up to $2 \mathrm{~km}$ at $40 \mathrm{~km}$ altitude. This indicates that the OCS signal is actually from somewhat further below and that symmetrical averaging kernels would lead to lower OCS values. The vertical resolution (Fig. 2, bottom) degrades from 4 to $5 \mathrm{~km}$ in the troposphere to more than $10 \mathrm{~km}$ in the upper stratosphere. The total estimated error (sum of measurement noise and uncertainties in interfering species and instrumental properties) is between 41 and 48 pptv (10-26\%) in the troposphere and lower stratosphere, and increases to $120 \mathrm{pptv}(195 \%)$ at $40 \mathrm{~km}$ altitude (Table 1). The dominating error component is measurement noise, while the error contributions from interfering species and instrumental parameters are comparatively weak.

\section{Validation}

A dedicated validation of MIPAS OCS amounts measured in the tropical upper troposphere and extra-tropical lowermost stratosphere has been presented in the Supplement of Glatthor et al. (2015a). In this investigation a comparison has been performed with airborne in situ data obtained on several campaigns of continental extent or nearly ranging from pole to pole. The outcome was a good agreement of MIPAS OCS with the airborne data, mostly with deviations of less than 25 pptv. Here we present a validation for a larger altitude range extending from the troposphere to the middle stratosphere. 

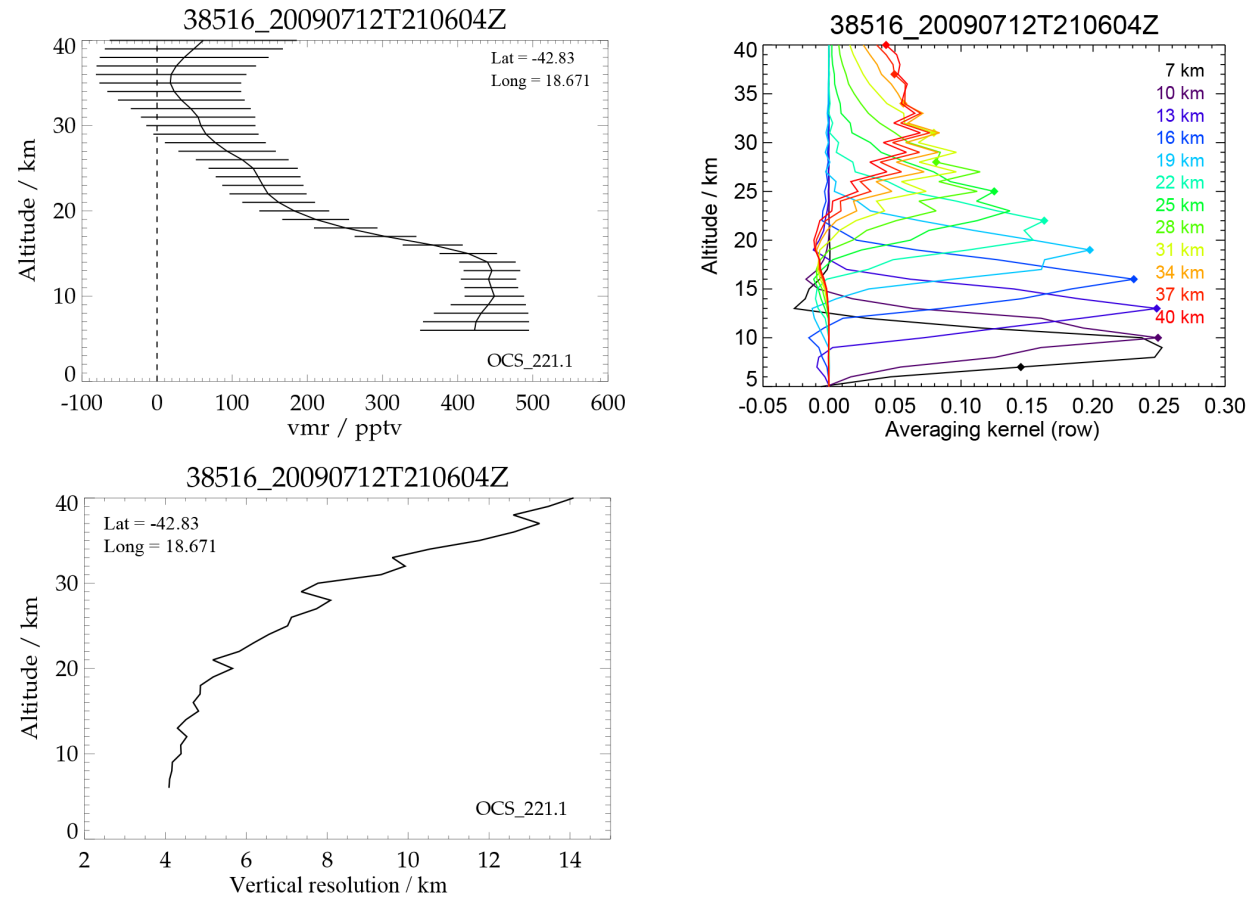

Figure 2. Top left: MIPAS OCS profile obtained from measurements at southern mid-latitudes $\left(42.8^{\circ} \mathrm{S}, 18.7^{\circ} \mathrm{E}\right)$ on $12 \mathrm{July} 2009$ along with the measurement noise error. Top right: Rows of the respective averaging kernels (AKs). For a clearer view only every third AK is plotted. The diamonds indicate the nominal altitudes of the different AK rows. Bottom: respective vertical resolution, derived from the width of the rows of the averaging kernels.

Table 1. Error budget for an OCS retrieval from spectra recorded on 12 July 2009 at $42.8^{\circ} \mathrm{S}, 18.7^{\circ} \mathrm{E}$ for selected altitudes. The errors are given in units of pptv, values in parentheses are relative errors in \%. The total error is the sum of measurement noise and parameter error. The parameter error is the sum of uncertainties in interfering species and instrumental properties.

\begin{tabular}{crrrrrrrr}
\hline $\begin{array}{c}\text { Height } \\
(\mathrm{km})\end{array}$ & $\begin{array}{r}\text { Total } \\
\text { Error }\end{array}$ & $\begin{array}{r}\text { Measurement } \\
\text { Noise }\end{array}$ & $\begin{array}{r}\text { Parameter } \\
\text { Error }\end{array}$ & $\mathrm{NH}_{3}$ & $\begin{array}{r}\text { Line of } \\
\text { Sight }\end{array}$ & Gain & Shift & Temperature \\
\hline 10 & $45(10.0)$ & $40(8.9)$ & $21(4.7)$ & $17(3.8)$ & $6.5(1.4)$ & $6.6(1.5)$ & $1.1(0.2)$ & $0.54(0.1)$ \\
15 & $41(9.9)$ & $38(9.2)$ & $14(3.4)$ & $3.4(0.8)$ & $12(2.9)$ & $4.5(1.1)$ & $0.76(0.2)$ & $0.60(0.1)$ \\
20 & $48(26.3)$ & $46(25.2)$ & $12(6.6)$ & $6.1(3.3)$ & $8(4.4)$ & $2.2(1.2)$ & $4.0(2.2)$ & $0.36(0.2)$ \\
25 & $60(46.9)$ & $59(46.1)$ & $6.4(5.0)$ & $4.6(3.6)$ & $2.3(1.8)$ & $0.98(0.8)$ & $2.3(1.8)$ & $0.09(0.1)$ \\
30 & $73(125)$ & $73(125)$ & $5.5(9.4)$ & $4.8(8.2)$ & $0.45(0.8)$ & $0.91(1.6)$ & $2.1(3.6)$ & $0.09(0.1)$ \\
40 & $120(195)$ & $120(195)$ & $8.4(13.7)$ & $7.3(11.9)$ & $2.4(3.9)$ & $0.84(1.4)$ & $3.0(4.9)$ & $0.07(0.1)$ \\
\hline
\end{tabular}

\subsection{Comparison with MkIV balloon interferometer profiles}

Figure 3 shows a comparison of MIPAS OCS data with OCS profiles obtained by the balloon-borne MkIV FTIR spectrometer (Toon, 1991). The MkIV profiles were obtained on 16 December 2002 and 1 April 2003 over Esrange, Sweden $\left(67.9^{\circ} \mathrm{N}, 21.1^{\circ} \mathrm{E}\right)$, and on 19 September 2003 and 2324 September 2011 over Fort Sumner, New Mexico, USA, $\left(34.5^{\circ} \mathrm{N}, 104.2^{\circ} \mathrm{W}\right)$. Unlike MIPAS retrievals at IMK, evaluation of OCS from MkIV spectra is performed in the spectral region 2041-2077 $\mathrm{cm}^{-1}$. The displayed MIPAS profiles are averages of all measurements within a radius of $1000 \mathrm{~km}$ and a temporal offset of $24 \mathrm{~h}$ ( $48 \mathrm{~h}$ for 19 September 2003) around the tangent points and measurement times of the balloon profiles, which resulted in averaging of 10-14 profiles for the different days. The dotted lines denote the standard deviation of the MIPAS profiles taken into account. On all days except for 16 December 2002, the deviations between the MIPAS and MkIV profiles are less than or equal to $\pm 60 \mathrm{pptv}$, and the OCS values of MIPAS are within the uncertainties of the balloon profiles at nearly all altitudes. On 16 December 2002 there are somewhat larger differences of up to $\pm 75 \mathrm{pptv}$. A potential reason for the deviations above $15 \mathrm{~km}$ altitude on this day is sounding of different air masses 
at the vortex edge. In summary, no clear indication of a bias against MkIV profiles has been found.

\subsection{Comparison with SPIRALE balloon in situ profiles}

In Fig. 4 we present an intercomparison of MIPAS OCS measurements with balloon-borne in situ measurements by the Spectromètre Infrarouge D'Absorption Lasers Embarqués (SPIRALE), which were performed on 9 June 2008 over Teresina, Brazil $\left(5.1^{\circ} \mathrm{S}, 42.1^{\circ} \mathrm{W}\right)$, and on 24 25 August 2009 over Esrange, Sweden $\left(67.9^{\circ} \mathrm{N}, 21.1^{\circ} \mathrm{E}\right)$ (Krysztofiak et al., 2014). The instrumental concept consists of six mid-infrared laser beams, which are reflected between two mirrors in a multipass cell located below the gondola (Moreau et al., 2005). OCS was retrieved in the wavenumber region 2056.1-2056.5 $\mathrm{cm}^{-1}$ using the HITRAN12 spectroscopy (Rothman et al., 2013). Again, the displayed MIPAS profiles are averages of all measurements within a radius of $1000 \mathrm{~km}$ and a temporal offset of $24 \mathrm{~h}$ around the tangent points and measurement times of the balloon profiles, which resulted in averaging of 18 and 26 profiles for the Teresina and Kiruna flight, respectively. Since the original SPIRALE profiles are vertically much better resolved than the MIPAS profiles, they are much more structured. For comparison of the two experiments the balloon profiles have additionally been convolved with the MIPAS averaging kernels. On both days there is good agreement between the two instruments. On 9 June 2008 the deviations are between $-50 \mathrm{pptv}$ at $16 \mathrm{~km}$ and $15 \mathrm{pptv}$ at $26 \mathrm{~km}$ altitude. On 24-25 August 2009 the differences range between $30 \mathrm{pptv}$ at 15 and $-10 \mathrm{pptv}$ at $18 \mathrm{~km}$ altitude. Thus, there is also no clear indication of a bias against SPIRALE profiles.

\subsection{Comparison with ACE-FTS}

Another global OCS data set was derived from spaceborne measurements of the ACE-FTS experiment on SCISAT (Bernath et al., 2005; Boone et al., 2005). Different to the MIPAS retrieval setup, the region $2039-2057.5 \mathrm{~cm}^{-1}$ is used for ACE-FTS retrievals of OCS (Hughes et al., 2016), and the line list of the HITRAN 2004 database (Rothman et al., 2005 ) is applied. In Fig. 5 we show an intercomparison of mean OCS profiles of coincident MIPAS and ACE-FTS observations. The ACE-FTS profiles taken into account are data version v3.5 (Boone et al., 2013). The comparison is based on 9452 ACE-FTS and 19990 MIPAS profiles of the time period February 2004 to April 2012. For each ACE-FTS profile all MIPAS profiles within a maximum temporal offset of $5 \mathrm{~h}$ and a maximum spatial distance of $500 \mathrm{~km}$ were taken into account. Then all coincident profiles of the two data sets were averaged for six different $30^{\circ}$-wide latitude bands. The profiles obtained by the two instruments exhibit significantly different shapes. While the MIPAS OCS VMRs increase by up to 40 pptv from the middle to the upper troposphere, the OCS amounts measured by ACE-FTS in this height range are con- stant or slightly decrease with altitude. Consequently, there is a positive bias between MIPAS and ACE-FTS in the height region $8-20 \mathrm{~km}$. The differences are largest around $14 \mathrm{~km}$, where they amount to $75-100 \mathrm{pptv}$. In the stratosphere the OCS profiles obtained by both sensors exhibit a strong decrease, and there is rather good agreement above $20 \mathrm{~km}$ altitude.

The reason for the large differences between the OCS amounts obtained by MIPAS and ACE-FTS is unclear. A possible explanation is the use of different spectral regions for OCS retrieval (see above). However, in this case it is difficult to explain the vanishing deviations below 10 and above $20 \mathrm{~km}$ altitude. In support of the higher MIPAS OCS values we refer to Velazco et al. (2011), who found ACE-FTS OCS data to be biased low by $\sim 15 \%$ compared to MkIV results in the altitude range $12-23 \mathrm{~km}$, although both data sets are retrieved in the same spectral region. Further, Krysztofiak et al. (2014) reported on a low bias of ACE-FTS OCS compared to the SPIRALE profiles presented in Section 3.2, which are also retrieved in the same spectral region as used for ACEFTS analysis of OCS. The mean ACE-FTS profile, with respect to the SPIRALE profile of Teresina, is $15-20 \%$ lower below $22.5 \mathrm{~km}$ altitude and the mean ACE-FTS profile in relation to the Kiruna flight is $20 \%$ lower at $16.5 \mathrm{~km}$ altitude. In addition, the validation results of Velazco et al. (2011) and Krysztofiak et al. (2014) are also in agreement with our intercomparison of MIPAS OCS data with MkIV and SPIRALE measurements. The local maxima of the MIPAS profiles in the upper troposphere might partly be due to retrieval instabilities. However, we cannot exclude that they are realistic.

\section{Results and discussion}

\subsection{Data set overview}

As a general overview, Figure 6 shows time series of monthly zonal averages of OCS at $10-30 \mathrm{~km}$ altitude, covering the operational period of MIPAS from July 2002 to April 2012. Spatial averaging was performed for $7.5^{\circ} \times 1 \mathrm{~km}$ latitudealtitude bins at the poles and $5^{\circ} \times 1 \mathrm{~km}$ bins elsewhere. This resulted in the summation of generally $500-1000$ values per month in each latitude-altitude bin except for the altitudes of 10 and $14 \mathrm{~km}$ in the inner tropics, where the number of points per bin decreases significantly due to strong cloud contamination, which reduces the number of usable measurements. Thus the tropical bins at $10 \mathrm{~km}$ altitude contain 69 individual data points on average and no measurements at all at the beginning of 2011 in the inner tropics. Measurements at $10 \mathrm{~km}$ altitude above Indonesia and the western Pacific warm pool are nearly permanently impeded by clouds, while cloud contamination in the remaining tropical latitude band exhibits a moderate seasonal variation. Caused by contamination by polar stratospheric clouds, the number of data points can also be considerably reduced inside the polar vortices. The data 

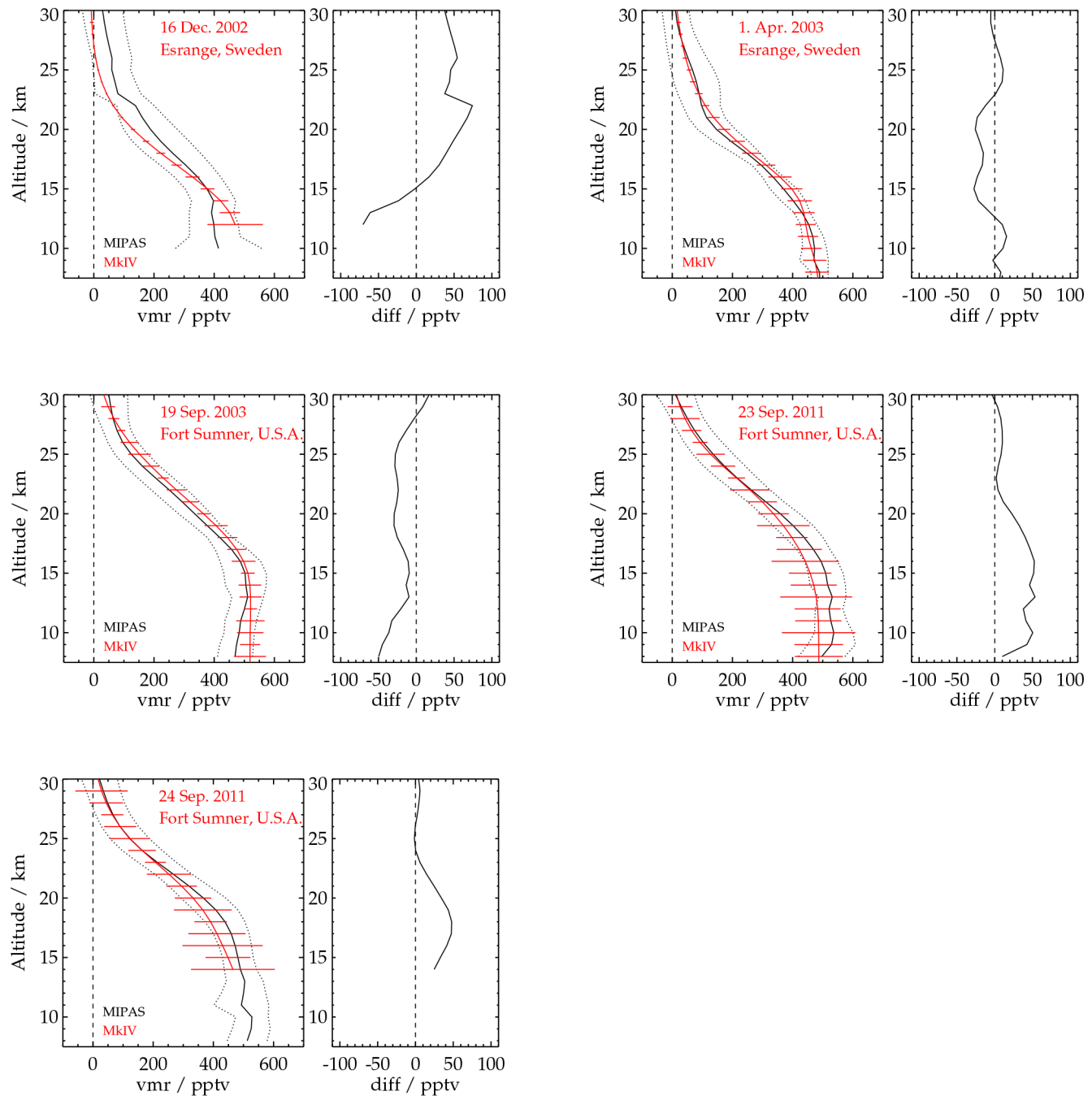

Figure 3. Comparison of MIPAS OCS data (black) with OCS profiles obtained by the MkIV balloon experiment (red) on 16 December 2002 and 1 April 2003 over Esrange, Sweden, $\left(67.9^{\circ} \mathrm{N}, 21.1^{\circ} \mathrm{E}\right.$, top panel) and on 19 September 2003, 23 and 24 September 2011 over Fort Sumner, New Mexico (34.5 $\mathrm{N}, 104.2^{\circ} \mathrm{W}$, middle panel and bottom). For each balloon profile all MIPAS profiles within a radius of $1000 \mathrm{~km}$ and a temporal offset of $24 \mathrm{~h}$ ( $48 \mathrm{~h}$ for 19 September 2003) were taken into account and averaged, resulting in adding up of 10-14 profiles, respectively. The dotted lines indicate the standard deviation of the MIPAS profiles and the error bars (red) the $1 \sigma$ measurement precision of the balloon profiles. The balloon profiles were convolved with the averaging kernels related to one of the collocated MIPAS profiles, respectively.

gap during most of the year 2004 results from the operational shutdown between MIPAS HR and RR measurement periods.

At most altitudes there is no distinct bias between the OCS amounts of the HR and of the RR period, indicating consistent OCS amounts over the whole operational period. However, at $14 \mathrm{~km}$ the OCS amounts of the RR period are significantly higher (by $\sim 25 \mathrm{pptv}$ in the tropics, by $\sim 50 \mathrm{pptv}$ at mid- and high latitudes) than those of the HR period. A closer look shows that the period of higher OCS amounts does not coincide with the beginning of the RR mode immediately after the data gap, but starts some months later in June 2005. Another slight increase occurs in 2006, just as at $18 \mathrm{~km}$ altitude. The reason for this increase, either geophysi- cal or instrumental, is unclear. Apart from these offsets there is no indication of a strong trend in the time series. A dedicated trend analysis will be performed in Sect. 4.4.

Generally, there are only weak interannual variations at all altitudes. At $10 \mathrm{~km}$ there is a clear annual variation in the Northern Hemisphere, with maxima around May-June in the tropics and around September-October at high latitudes. In the tropics the lowest OCS values were measured at the end of the year and at Arctic latitudes around March-April. In the Southern Hemisphere there is a less distinct annual cycle, and the maxima are somewhat weaker. The OCS amounts peak around July at low southern latitudes and around May at southern mid-latitudes. The OCS amounts at the altitude 

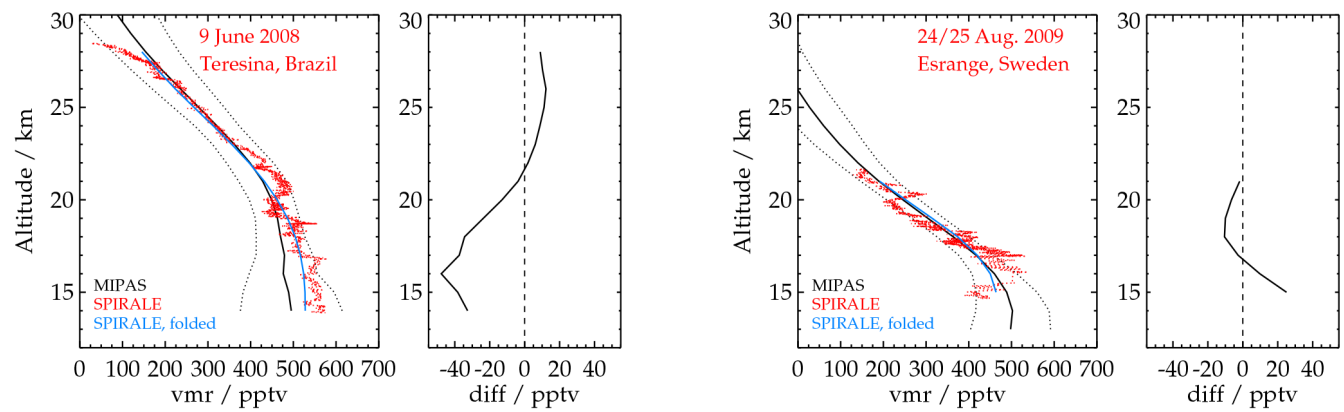

Figure 4. Comparison of MIPAS OCS data (black) with OCS balloon profiles obtained by the SPIRALE experiment (red) on 9 June 2008 over Teresina, Brazil $\left(5.1^{\circ} \mathrm{S}, 42.1^{\circ} \mathrm{W}\right.$, left), and on 24-25 August 2009 over Esrange, Sweden $\left(67.9^{\circ} \mathrm{N}, 21.1^{\circ} \mathrm{E}\right.$, right). The displayed MIPAS data are averages, for which all profiles within a radius of $1000 \mathrm{~km}$ and a temporal offset of 24 hours with respect to the SPIRALE profiles were taken into account. The dotted lines indicate the standard deviation of the MIPAS profiles, and the blue curves are the SPIRALE profiles convolved with MIPAS averaging kernels.
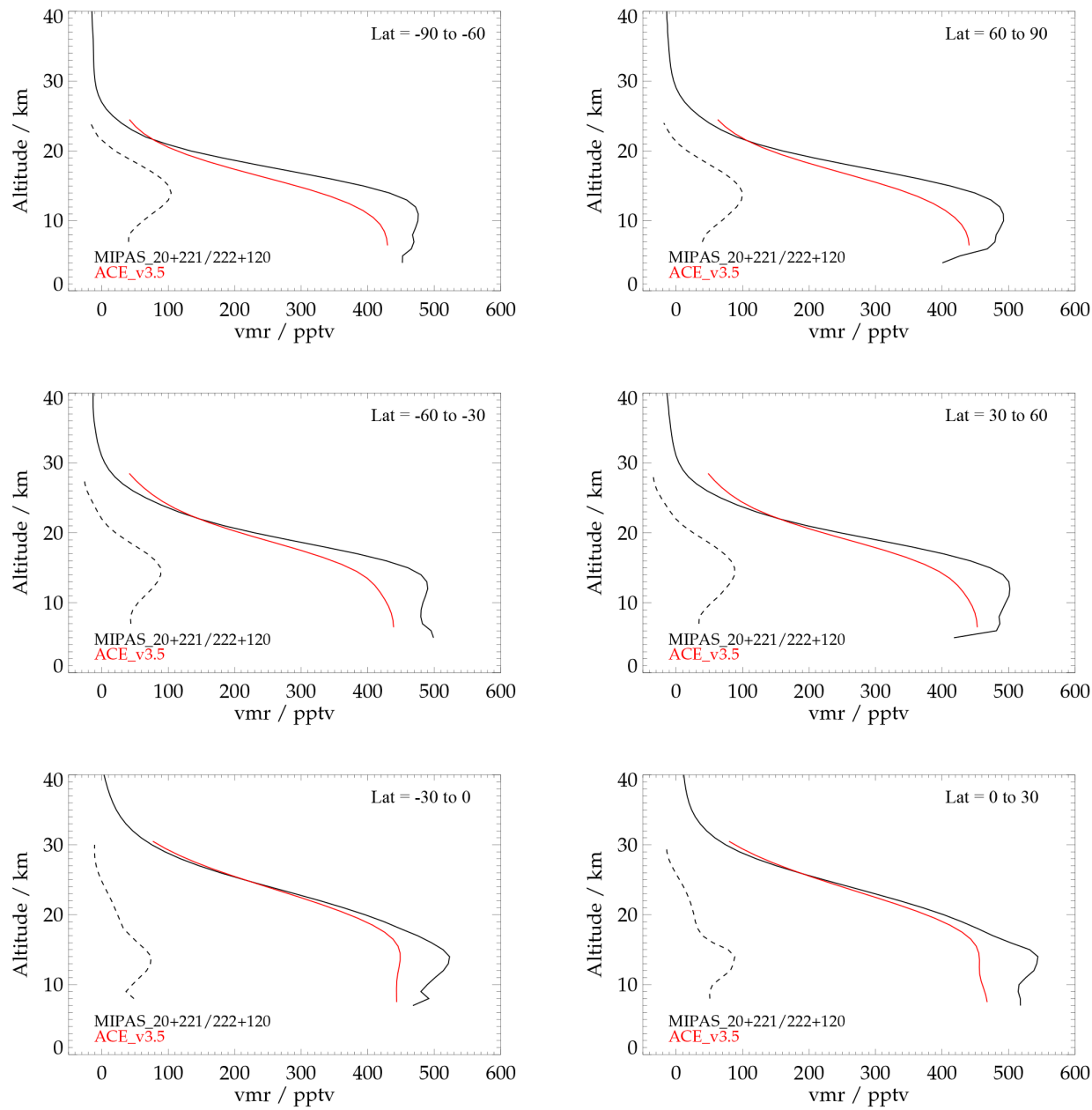

Figure 5. Comparison of OCS data obtained by MIPAS (solid black curves) and by ACE-FTS (v3.5) (red curves) in the latitude bands 60$90^{\circ}$ (top row), 30-60 (middle row) and 0-30 (bottom row), both for the Southern (left) and Northern Hemisphere (right). The displayed profiles are averages of collocated data in the respective latitude bands. For each ACE-FTS profile, MIPAS data within a maximum temporal offset of $5 \mathrm{~h}$ and a maximum spatial distance of $500 \mathrm{~km}$ were taken into account. Only ACE-FTS OCS data with quality_flag $=0$ were used. The ACE-FTS profiles were convolved with the averaging kernels related to a MIPAS OCS retrieval. Dashed black curves are the differences between MIPAS and ACE-FTS. 


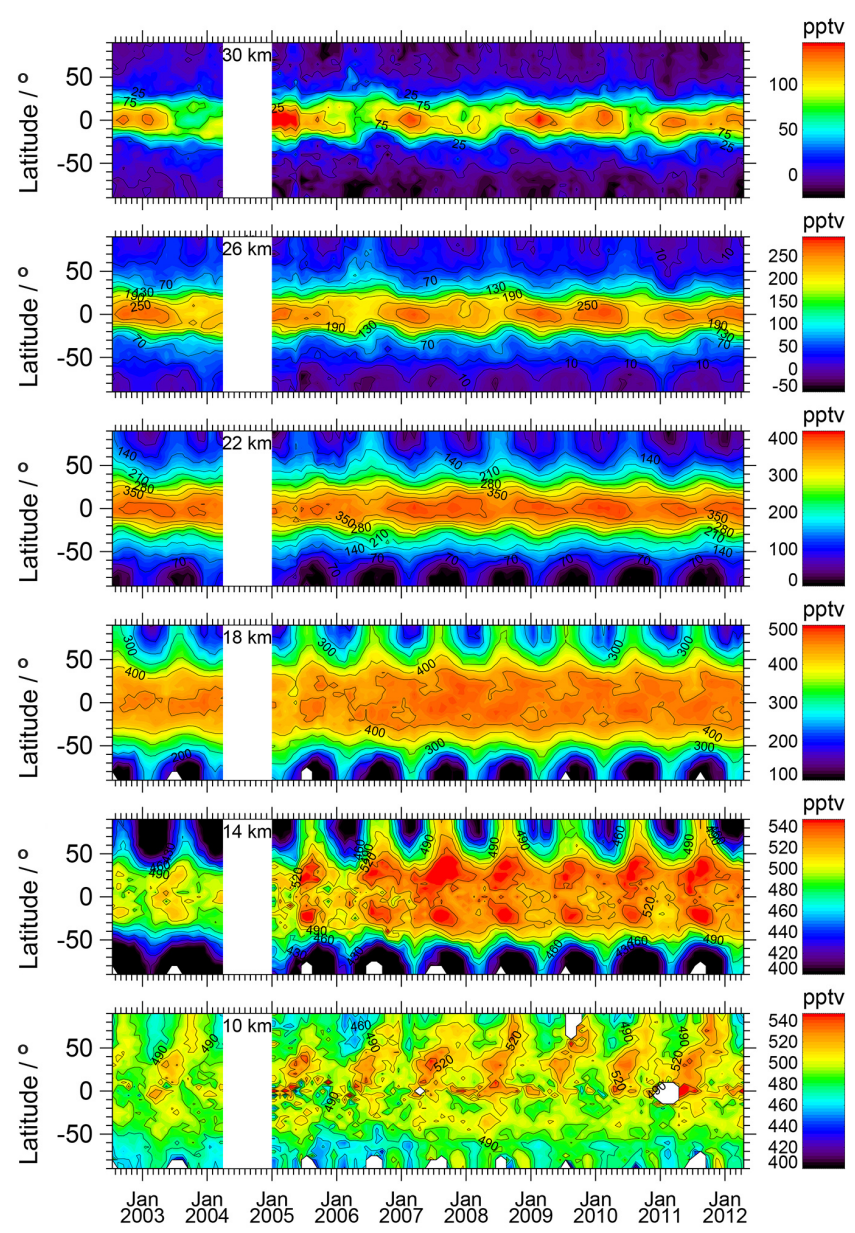

Figure 6. Time series of monthly and zonally averaged OCS measured by MIPAS at 30, 26, 22, 18, 14 and $10 \mathrm{~km}$ (top to bottom). The white area in 2004 is a data gap due to operational shutdown of MIPAS and the remaining white areas are caused by cloud contamination. Note the different colour ranges. Values outside of the colour ranges are also labelled in black or red, respectively.

of $14 \mathrm{~km}$ also exhibit annual cycles at northern as well as at southern latitudes. In the Southern Hemisphere the annual cycle at this altitude is more distinct than at $10 \mathrm{~km}$. While the magnitude of low- and mid-latitude OCS amounts at $14 \mathrm{~km}$ is approximately the same as at $10 \mathrm{~km}$ until mid-2005, it is higher in the subsequent time period. The Arctic minima between December and March and the Antarctic minima from March until the end of the year are obviously caused by subsidence of OCS-poor air masses in the polar vortices. At $18 \mathrm{~km}$ the annual variations at low and mid-latitudes become weaker, while high latitudes are also characterized by vortex dynamics. At $22-30 \mathrm{~km}$ the OCS variations are further weakened and in the tropics the 1-year cycle is superposed by a 2-year period, indicating the impact of the quasi-biennial oscillation (QBO).

Figure 7 shows MIPAS OCS profiles of the latitude bands $0-30,30-60$ and $60-90^{\circ}$ for both the Northern and Southern
Hemisphere. The profiles are seasonal averages of the whole OCS data set. Up to $13-15 \mathrm{~km}$ the mixing ratios of the tropical and mid-latitude profiles vary only a little between about 490 and $530 \mathrm{pptv}$. The respective variation at high latitudes is somewhat larger. In the stratosphere the profiles strongly decrease to below $100 \mathrm{pptv}$ around $20 \mathrm{~km}$ at high latitudes and at $30 \mathrm{~km}$ in the tropics. The largest seasonal variations occur in the Arctic and Antarctic lower stratosphere, reflecting subsidence of OCS-poor air masses in the polar vortices during winter and spring and the recovery during summer and fall. The subsidence is stronger and continues until austral spring in the Antarctic vortex.

The seasonal variations in the troposphere are generally larger in the Northern Hemisphere. In the northern tropics and subtropics the OCS amounts between 7 and $12 \mathrm{~km}$ are $510-530$ pptv in boreal spring and summer and about 20-30 pptv lower during boreal fall and winter. The highest OCS amounts of 500-520 pptv at northern mid-latitudes were measured during boreal summer. At northern high latitudes the tropospheric maximum is temporally further shifted into boreal fall. These variations are caused by overlap of oceanic release and of vegetative uptake of OCS during the growing season, which affects the free troposphere with a certain delay, and especially in the tropopause region at higher latitudes by subsidence of OCS-poor air masses in the polar vortex during winter and subsequent recovery. At southern low and mid-latitudes there are only small tropospheric variations, and the mixing ratios in austral summer are somewhat lower than those in the Northern Hemisphere during boreal summer.

\subsection{Latitudinal cross sections}

\subsubsection{Annual means}

Since OCS is assumed to be relatively well mixed in the troposphere, we compared the latitudinal variation of MIPAS OCS amounts at $8 \mathrm{~km}$ altitude with ground-based flask data from the NOAA ESRL network, taken from the website at http://www.esrl.noaa.gov/gmd/hats/gases/OCS.html. The result of the comparison is shown in Fig. 8, where both data sets are averaged over the whole measurement period of MIPAS. This kind of temporal averaging eliminates a potential bias due to the time required for vertical transport of seasonal variations to the upper troposphere. Between southern mid-latitudes and northern subtropics there are differences of 10 pptv or less. The largest deviations occur at two groundbased stations at northern mid-latitudes, where the OCS amounts are lower by $50 \mathrm{pptv}$. These stations are located in the central (LEF, $45.9^{\circ} \mathrm{N}, 90.3^{\circ} \mathrm{W}$ ) and eastern United States (HFM, $42.5^{\circ} \mathrm{N}, 72.2^{\circ} \mathrm{W}$ ), where the OCS amounts are strongly reduced by vegetative uptake during the growing season (Montzka et al., 2007). Obviously this signal is hardly observable in zonal means in the upper troposphere. However, there is much better agreement of MIPAS OCS 

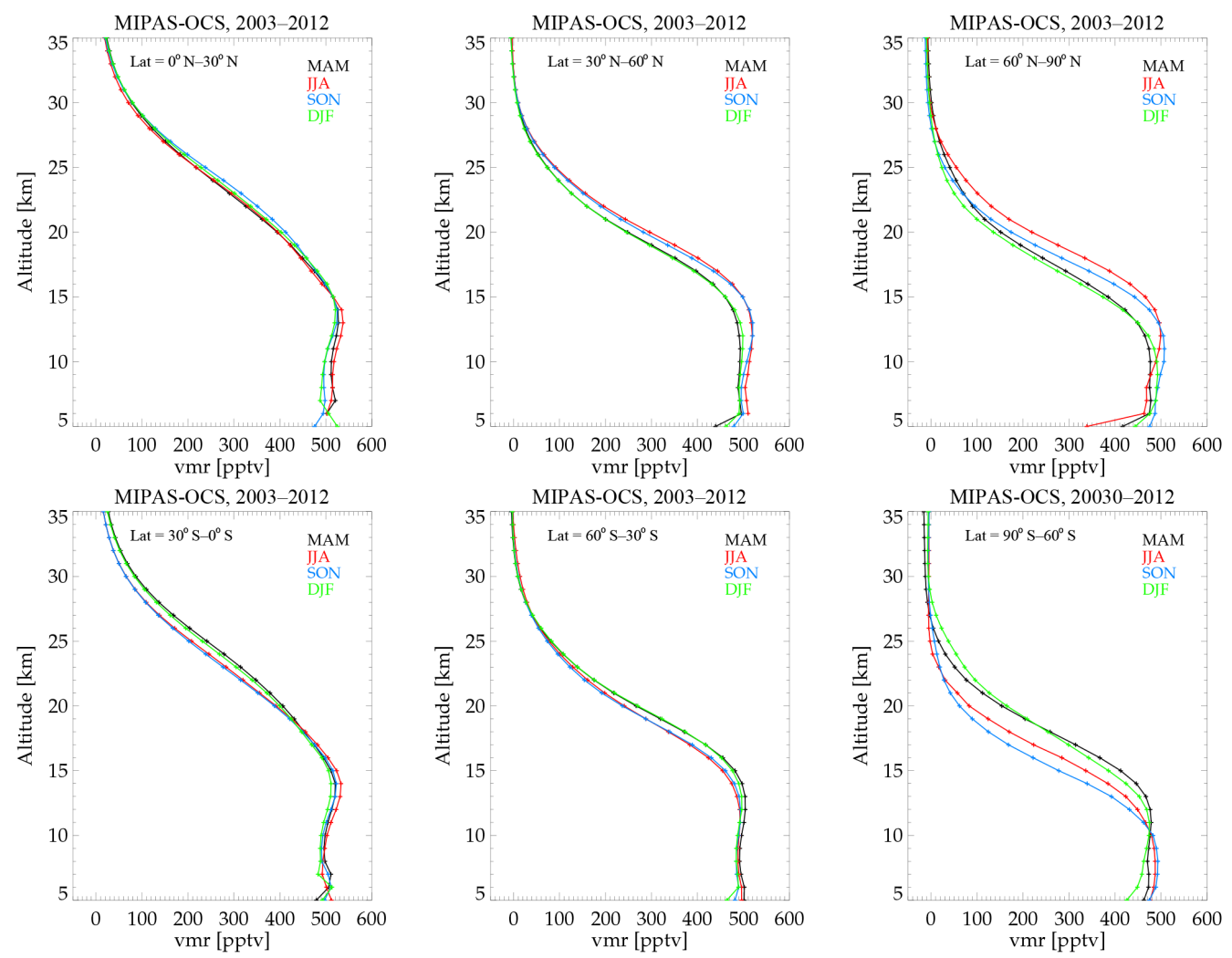

Figure 7. Mean OCS profiles measured by MIPAS in the latitude bands $0-30^{\circ} \mathrm{N}, 30-60^{\circ} \mathrm{N}, 60-90^{\circ} \mathrm{N}, 0-30^{\circ} \mathrm{S}, 30-60^{\circ} \mathrm{S}$ and $60-90^{\circ} \mathrm{S}$ (top left to bottom right) during different seasons. Colour coding of seasons: March-May (black), June-August (red), September-November (blue), December-February (green).

with the high-altitude station Niwot Ridge (NWR, $40.0^{\circ} \mathrm{N}$, $105.54^{\circ} \mathrm{W}, 3475 \mathrm{~m}$ a.s.1.), Colorado, where a decrease caused by vegetative uptake is also not visible. There is also better correspondence of MIPAS data from northern mid-latitudes with surface OCS data from Mace Head (MHD, 53.3 $\mathrm{N}$, $9.9^{\circ} \mathrm{W}, 42 \mathrm{~m}$ a.s.1.) in Ireland, where a potential signal of vegetative uptake advected from North America by the prevailing westerly winds is mixed with other air masses on its long way crossing the Atlantic Ocean. Due to the stronger impact of vegetative uptake on measurements in the boundary layer, the OCS amounts from the two stations near sea level at high northern latitudes, Barrow (BRW, $71.3^{\circ} \mathrm{N}, 155.6^{\circ} \mathrm{W}$ ) and Alert (ALT, $82.5^{\circ} \mathrm{N}, 62.3^{\circ} \mathrm{W}$ ), are also considerably lower than those observed by MIPAS at $10 \mathrm{~km}$. Again, there is better agreement with OCS amounts measured in the free troposphere at the station Summit (SUM, $72.6^{\circ} \mathrm{N}, 38.4^{\circ} \mathrm{W}$, $\sim 3200 \mathrm{~m}$ a.s.l.) on top of the Greenland ice shield. At high southern latitudes the ground-based OCS amounts remain on the same level as at mid-latitudes, while the OCS values at $10 \mathrm{~km}$ altitude exhibit a step-like decrease.

\subsubsection{Seasonal variations}

Figure 9 (left column) shows latitude-height cross sections of MIPAS OCS VMRs measured in winter, spring, summer and fall. The seasonal data sets are averaged over the whole measurement period of MIPAS (2002-2012). Averaging was performed for $7.5^{\circ} \times 1 \mathrm{~km}$ latitude-altitude bins at the poles and $5^{\circ} \times 1 \mathrm{~km}$ bins elsewhere. Above $10 \mathrm{~km}$ altitude the averaged MIPAS data are generally based on 10000 15000 values. Due to cloud contamination and to the upward shift of the MIPAS RR mode scans towards low latitudes, increasingly fewer data points could be binned at $10 \mathrm{~km}$ and below, e.g. only some dozens or even less than 10 values at $7 \mathrm{~km}$ altitude in the tropics.

Because of the long lifetime of OCS, the latitude-height cross sections of measured OCS appear to be rather similar through all seasons. Tropospheric OCS amounts are between $480 \mathrm{pptv}$ at high latitudes and $520 \mathrm{pptv}$ in the tropical upper troposphere. Further, the tropospheric cross sections are relatively symmetric with respect to the Equator. At mid- and high latitudes there is a strong vertical decline in OCS in the lower stratosphere. At tropical latitudes this transition region is shifted towards the middle stratosphere and vertically extended, which reflects upwelling in the Brewer- 


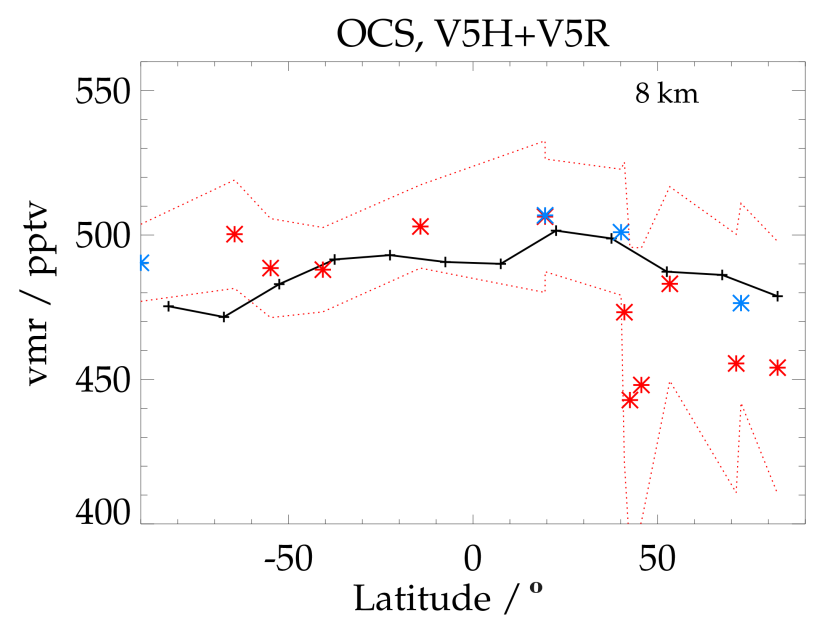

Figure 8. Latitudinal variation of MIPAS OCS data at $8 \mathrm{~km}$ altitude, averaged over the whole measurement period from 2002 to 2012 (black curve), and OCS amounts (flask data) from NOAA ESRL surface stations (stars), averaged over the same time period. Surface stations indicated by red stars are situated at low altitudes in the boundary layer and surface stations indicated by blue stars on mountains in the free troposphere. The red dotted curves represent the $1 \sigma$ standard deviation of the flask data.

Dobson circulation. During winter and spring, subsidence of stratospheric air masses with low OCS amounts is visible in the polar vortices. This process is more pronounced in the Antarctic vortex compared to the Arctic vortex.

For comparison, Fig. 9 (second column) shows cross sections of an ECHAM/MESSy Atmospheric Chemistry (EMAC) model run. Horizontal distributions of this simulation have already been presented in Glatthor et al. (2015a). The EMAC model is a numerical chemistry and climate simulation system that includes sub-models describing tropospheric and middle atmosphere processes and their interaction with oceans, land and human influences (Jöckel et al., 2006, 2010). It uses the second version of the Modular Earth Submodel System (MESSy2) to link multi-institutional computer codes. The core atmospheric model is the 5th generation European Centre Hamburg general circulation model (ECHAM5, Roeckner et al., 2006). In the EMAC simulations presented here, monthly varying OCS emissions taken from the scenario of Kettle et al. (2002) and modified by enhancement of the tropical vegetation uptake are applied as flux boundary conditions. More details of the model simulation can be found in Glatthor et al. (2015a). A comparison of MIPAS OCS with EMAC simulations from a different setup has been presented in Brühl et al. (2015).

Generally, the model cross sections are in good agreement with the measurements. They also show upwelling in the tropics, decreasing values in the stratosphere and towards higher latitudes, and subsidence in the polar vortices, but there are several differences. First, contrary to the measurements, the modelled tropospheric OCS amounts are not sym- metrical in relation to the Equator. They are in rather good agreement with the measurements in the Southern Hemisphere, but decrease towards high latitudes in the Northern Hemisphere. This asymmetry is most pronounced in boreal fall due to the strong vegetation uptake assumed in the model run. Secondly, the modelled transition region from hightropospheric to low-stratospheric mixing ratios is at somewhat higher altitudes than in the measurements. Thirdly, the MIPAS distributions apparently exhibit a stronger upwelling in the tropical stratosphere above $30 \mathrm{~km}$ than the model distributions. However, convolution of the EMAC data with the averaging kernels of a MIPAS OCS profile obtained in the tropics (right column) leads to much better agreement in the tropical upper stratosphere and to somewhat better agreement in the northern hemispheric troposphere and in the transition region between 15 and $25 \mathrm{~km}$ altitude. Thus the apparent stronger upwelling of measured OCS in the tropical upper stratosphere is an artefact caused by the displaced averaging kernels in this region (cf. Sect. 2.2). Further, convolution with the MIPAS averaging kernels also leads to a considerable attenuation of the modelled OCS minimum in the northern troposphere during boreal summer and fall.

\subsubsection{Mean hemispheric mixing ratios}

In Table 2 we show seasonal and annual averages of MIPAS OCS measurements in the northern and southern hemispheric troposphere. For this purpose the OCS VMRs in all zonal bins below the mean tropopause were averaged separately for both hemispheres. Tropopause heights were calculated from the temperature profiles obtained from MIPAS measurements and averaged in the same way as the OCS measurements. In both hemispheres the seasonal variation of average upper tropospheric OCS is only 10-11 pptv. The interhemispheric differences are also very low, leading to ratios close to unity. The ratio between the annual means of the Northern and Southern Hemisphere is $1.01 \pm 0.01$. The same ratio results for all seasons except for boreal spring, where it is 0.99. For comparison, the ratio between the OCS amounts observed by ACE-FTS during 2004-2006 in the northern and southern hemispheric troposphere is 1.03 (Barkley et al., 2008). The annual NH/SH ratio obtained from ground-based measurements of the NOAA ESRL network between 2000 and 2005 is slightly lower than unity, namely $0.97 \pm 0.01$ (Montza et al., 2007). In the course of the year this ratio varies between 1.02 in boreal spring, 0.98 in boreal summer, 0.92 in boreal fall and 0.95 in boreal winter. In this estimation the results from the stations Trinidad Head (THD, $\left.41.0^{\circ} \mathrm{N}, 124.1^{\circ} \mathrm{W}\right)$, MHD and SUM had been excluded, because they did not cover the whole measurement period. Additional omission of the two sites in the mid-continental and eastern United States (LEF, HFM) led to an annual mean $\mathrm{NH} / \mathrm{SH}$ ratio of 1.00, which is in good agreement with the ratio for MIPAS OCS and indicates that the interhemispheric imbalance is caused by the strong vegetation uptake of OCS 

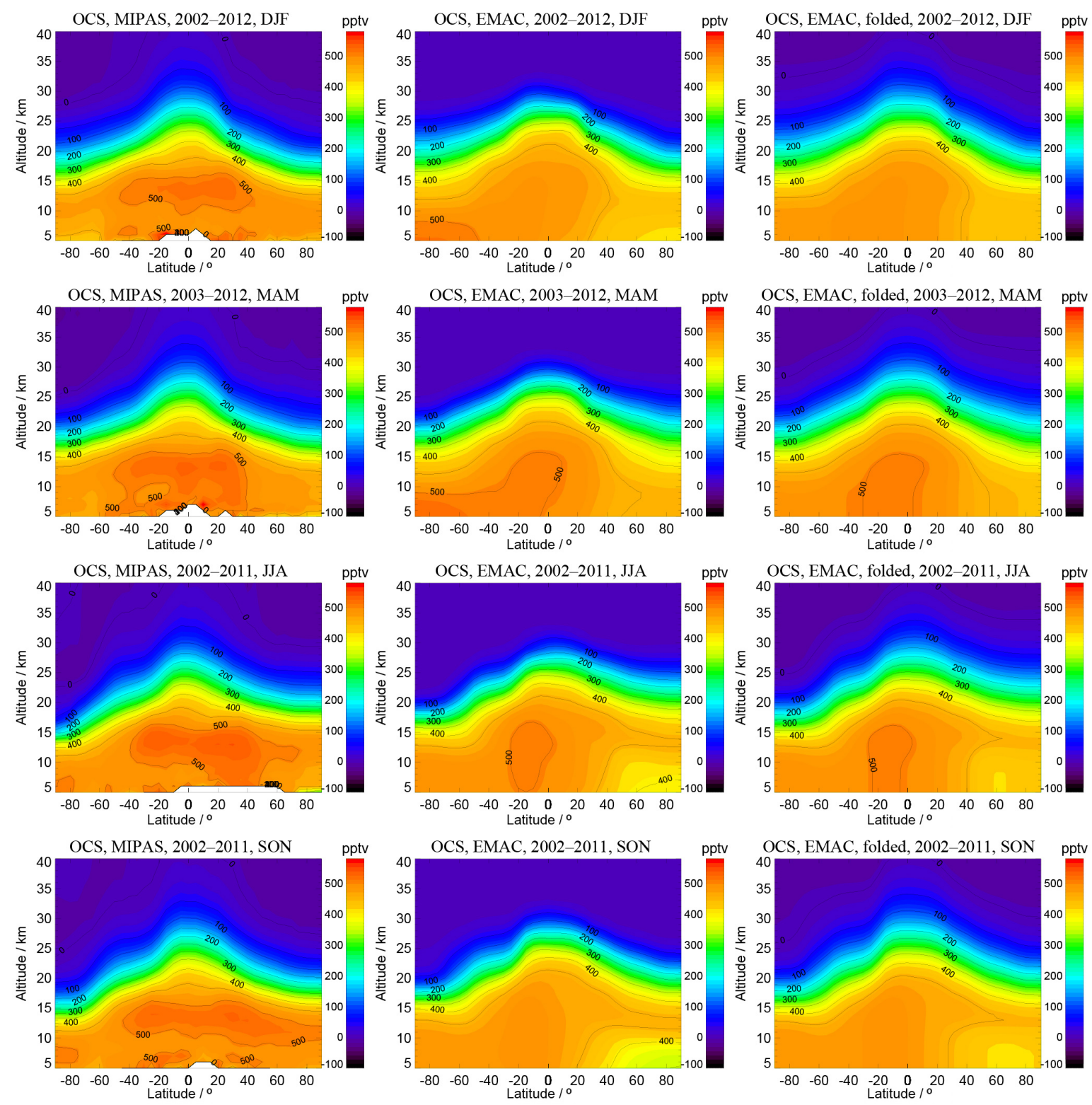

Figure 9. Left: OCS latitude-height cross sections measured by MIPAS between 2002 and 2012 during December to February, March to May, June to August and September to November (top to bottom). Middle: same as left but for EMAC OCS model results. Right: same as left, but for EMAC OCS model results convolved with a MIPAS averaging kernel of a tropical OCS profile.

Table 2. Seasonal and annual averages of OCS amounts measured by MIPAS between June 2002 and April 2012 in the northern and southern hemispheric troposphere and the ratio between hemispheric averages. MAM: March to May, JJA: June to August, SON: September to November, DJF: December to February.

\begin{tabular}{lccc}
\hline Season & \multicolumn{2}{c}{ Average OCS amounts in pptv } & Ratio NH / SH \\
& Northern Hemisphere & Southern Hemisphere & \\
\hline MAM & 493.51 & 496.46 & $0.99 \pm 0.01$ \\
JJA & 502.03 & 495.60 & $1.01 \pm 0.01$ \\
SON & 498.51 & 495.51 & $1.01 \pm 0.01$ \\
DJF & 491.62 & 484.88 & $1.01 \pm 0.01$ \\
Annual & 494.42 & 491.37 & $1.01 \pm 0.01$ \\
\hline
\end{tabular}



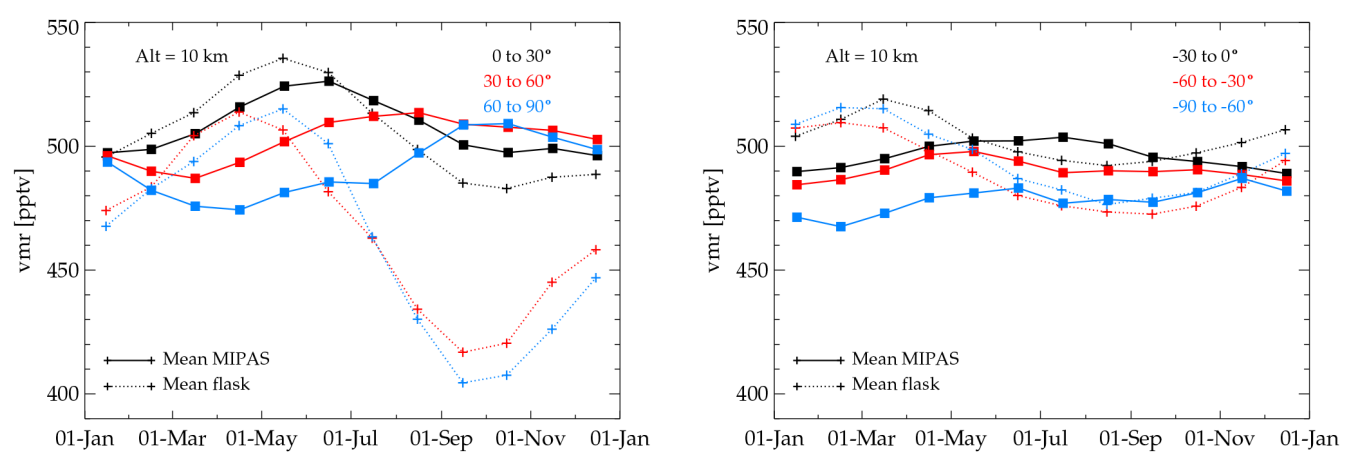

Figure 10. Monthly variation of OCS amounts measured by MIPAS during 2002-2012 (solid lines) and at surface stations (dotted lines) in the latitude bands $0-30^{\circ}$ (black), $30-60^{\circ}$ (red) and 60-90 (blue) in the Northern (left) and Southern Hemisphere (right). Surface data are averaged over all ESRL stations in the respective latitude bands and over the whole measurement period of MIPAS.

observed at these two sites during summer and fall (Montzka et al., 2007).

\subsubsection{Monthly variations in different latitude bands}

For a more quantitative investigation of seasonal variations, Fig. 10 shows monthly averages of measured OCS amounts in six $30^{\circ}$-wide latitude bands at $10 \mathrm{~km}$ altitude along with the monthly averages of all ground stations of the NOAA ESRL network in the respective latitude band. In both data sets there are distinct seasonal variations in all latitude bands, which generally are larger at the ground than at $10 \mathrm{~km}$ altitude. Further, the variations in the Northern Hemisphere are stronger than those at southern latitudes.

Due to the strong seasonal cycle in northern hemispheric vegetation uptake, the largest variations of up to more than 100 pptv occur at northern hemispheric mid- and highlatitude ground-based stations. The OCS amounts observed at these stations peak in April-May just before the onset of vegetative uptake and are lowest in September. The respective variations in MIPAS OCS at $10 \mathrm{~km}$ altitude are 30 40 pptv and exhibit a phase lag of 4-6 months. A similar behaviour, namely reduced amplitudes and a time delay of 1-2 months of OCS variations in the free troposphere compared to surface stations, was also reported by Montzka et al. (2007) for airborne measurements above the United States. The much larger time shift in the MIPAS OCS variations is caused by overlay of vortex dynamics, i.e. subsidence of OCS-poor air masses in the polar vortex leading to a minimum in spring and subsequent recovery until late summer. In the northern tropics and subtropics there is a temporal shift of one month at the most between measured ground-based and upper tropospheric variations, which apparently reflects faster upward propagation than at higher latitudes.

Ground-based OCS amounts in the Southern Hemisphere have peak-to-peak amplitudes of about 35 pptv, with maxima in February-March and minima in August-September. The respective variations observed by MIPAS at $10 \mathrm{~km}$ altitude are 15-20 pptv. Compared to the surface measurements, the southern hemispheric maxima observed by MIPAS are delayed by 3 to 4 months.

\subsection{Horizontal distributions}

\subsubsection{Tropical sources and sinks, meridional decline}

Figure 11 shows OCS amounts measured at $250 \mathrm{hPa}$ during June to August (top left) and September to November (top right). This pressure level corresponds to $\sim 11 \mathrm{~km}$ in the tropics and $\sim 9.7 \mathrm{~km}$ at polar latitudes. The distributions are averaged over the whole measurement period of MIPAS from 2002 until 2012. The latitude-longitude binning is $7.5^{\circ} \times 15^{\circ}$ at the poles and $5^{\circ} \times 15^{\circ}$ at lower latitudes. The complete seasonal variation at this pressure level has already been presented in Glatthor et al. (2015a).

During June to August elevated OCS amounts of up to 540 pptv were observed over wide tropical and subtropical areas and even up to northern mid-latitudes, apparently caused by strong oceanic release and effective upward transport. The assumption of oceanic release as a major source of atmospheric OCS is supported by various budget estimations (e.g. Kettle et al., 2002; Berry et al., 2013) as well as by a model study of Launois et al. (2015). In addition to natural sources, Blake et al. (2004) and Lennartz et al. (2017) suggest a larger contribution of anthropogenic Asian emissions instead. During September to November the OCS amounts measured at low latitudes are reduced by $20-30$ pptv. Another striking feature is a large area of low OCS amounts extending from Brazil over the southern tropical Atlantic to southern Africa, which is caused by uptake by the tropical vegetation and is strongest in austral summer (cf. Glatthor et al., 2015a).

During boreal summer the OCS amounts measured at $250 \mathrm{hPa}$ exhibit a distinct decrease towards mid- and high latitudes, which is especially pronounced in the Southern Hemisphere. This decrease is partly due to the fact that at high latitudes this pressure level is in the tropopause region or even in the lowermost stratosphere. But it also indicates that the 

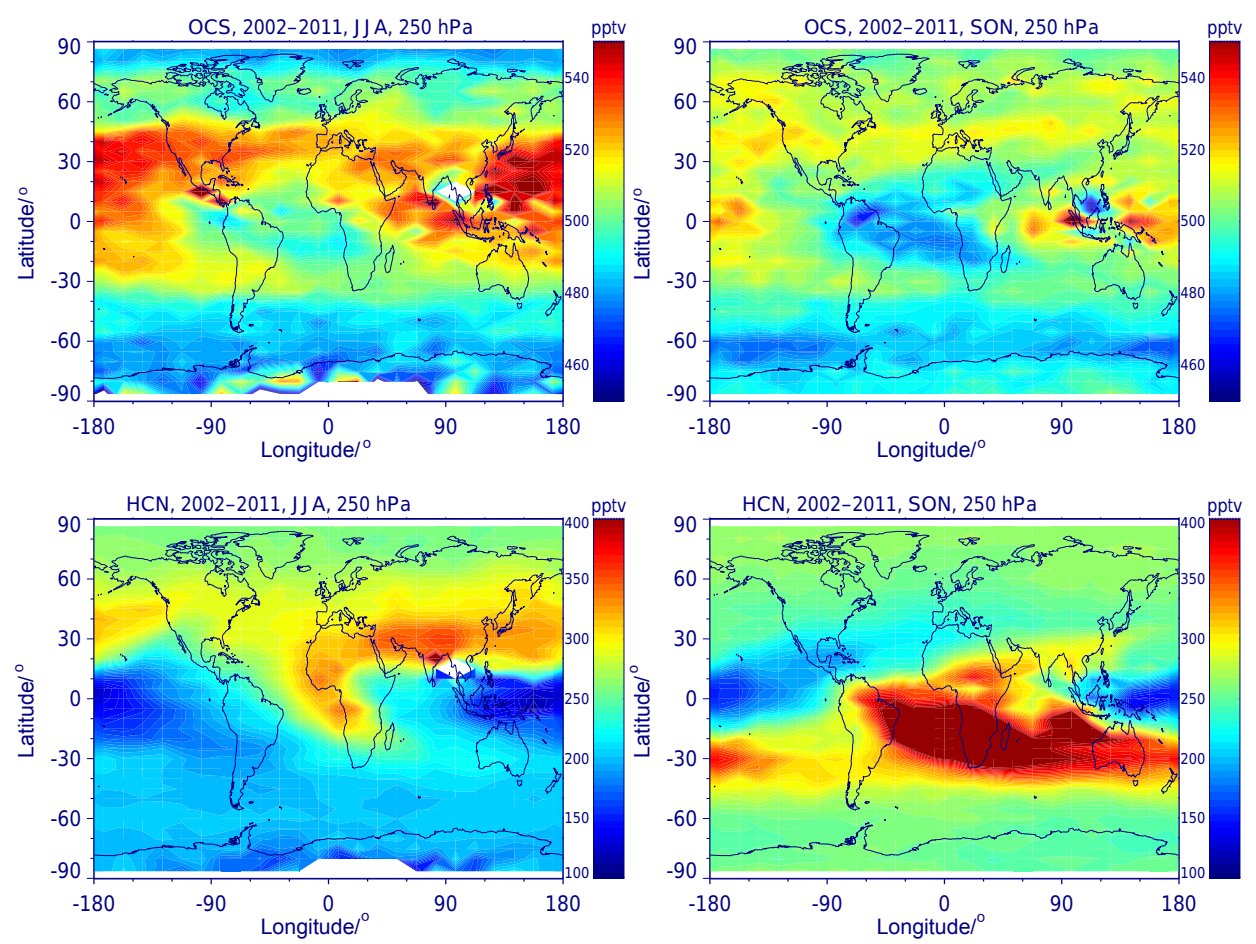

Figure 11. Top row: OCS distribution measured by MIPAS between 2002 and 2011 at the $250 \mathrm{hPa}$ level during the periods June to August (left) and September to November (right). Bottom row: same as top panel, but for MIPAS HCN.

main source regions of OCS are at low latitudes or that upward transport by strong convection is more effective at these latitudes. During boreal fall the decrease towards high southern latitudes is nearly the same, while the OCS amounts at mid- and high northern latitudes have increased, indicating northward transport of elevated OCS amounts observed at lower latitudes during summer or weaker vertical mixing.

\subsubsection{Biomass burning}

As outlined in Sect. 1 the role of biomass burning as a source of atmospheric OCS is controversial, although most budget estimations assume a minor contribution of biomass burning only. Because of this open question we checked the MIPAS OCS distributions on signatures of biomass burning by comparison with MIPAS HCN, which is an almost unambiguous tracer of biomass burning ( $\mathrm{Li}$ et al., 2003; Singh et al., 2003). Typical emission factors $\left(\mathrm{g} \mathrm{kg}^{-1}\right)$ of $\mathrm{HCN}$ for tropical biomass burning are $0.42(0.26)$ for tropical forests (Akagi et al., 2011) and $0.53(0.15)$ for savanna fires (Yokelson et al., 2003). The values in parentheses are estimates for the natural variation. OCS emission factors for tropical biomass burning have hardly been determined. Based on one canister sample, Yokelson et al. (2008) give a value of $0.025 \mathrm{~g} \mathrm{~kg}^{-1}$, which is more than 1 order of magnitude lower than the $\mathrm{HCN}$ emission factors and thus also points to comparably low OCS emissions from tropical fires.
A prominent feature of biomass burning is the southern hemispheric plume, which forms in boreal fall and mostly extends from Brazil over southern Africa to Australia and further eastward above the southern Pacific (Edwards et al., 2006; Coheur et al., 2007; von Clarmann et al., 2007; Glatthor et al., 2015b). This plume is reflected in strongly enhanced amounts of HCN observed during September to November 2002-2011 (Fig. 11, bottom right), but it is not visible in the MIPAS OCS distribution (Fig. 11, top right). On the contrary, the area between Brazil and southern Africa contains depleted OCS amounts instead. During boreal summer, signatures of biomass burning are generally detectable inside the Asian monsoon anticyclone (AMA), over central and western Africa and the north-western subtropical Pacific. Again, this is reflected in enhanced $\mathrm{HCN}$ amounts detected by MIPAS in these regions during June to August 2002-2011 (Fig. 11, bottom left). However, the distribution of enhanced OCS amounts observed by MIPAS during boreal summer appears rather different (Fig. 11, top left). It is much more widespread over the tropics and subtropics and apparently has strong sources around Indonesia and in the western Pacific.

For a more quantitative estimation we performed correlation analyses between upper tropospheric MIPAS OCS and MIPAS HCN for different years, seasons and latitude bands. We checked the whole OCS data set measured by MIPAS for potential signatures of biomass burning, but found neither strong correlations with, e.g., $\mathrm{HCN}$ or $\mathrm{CO}$, nor especially 

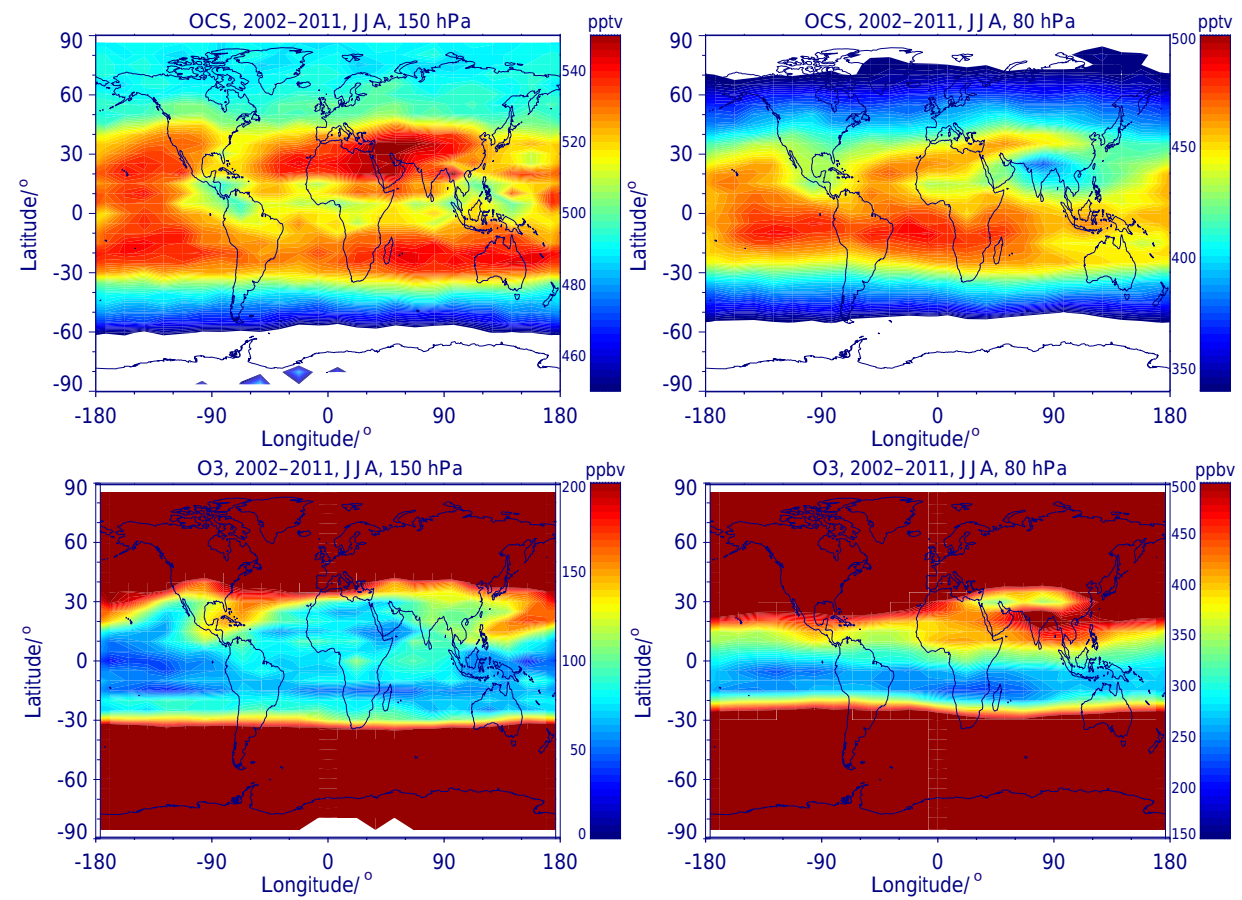

Figure 12. Top row: OCS distribution measured by MIPAS between June and August 2002-2011 at the $150 \mathrm{hPa}$ (left) and at the $80 \mathrm{hPa}$ level (right). Bottom row: same as top row, but for MIPAS $\mathrm{O}_{3}$.

enhanced OCS in the regions of typical biomass burning plumes. Table 3 shows the results of the correlation analysis for southern hemispheric biomass burning periods $\left(50^{\circ} \mathrm{S}-\right.$ $0^{\circ} \mathrm{N}$, September-December) during all years with available MIPAS data. For every year the correlation coefficient and the slope of the fitted regression line are close to zero. Moreover, for most of the years the slope is even slightly negative. Thus we conclude that compared to other sources, biomass burning plays only a minor role in the tropospheric OCS budget. The findings of Notholt et al. (2003) and Barkley et al. (2008) (see Sect. 1) cannot be confirmed on the basis of MIPAS data.

A possible reason for the positive slopes in 2002 and 2006 is intense biomass burning in Indonesia during these years, which were characterized by a strong positive phase of the El Niño-Southern Oscillation (ENSO) (http://www.cpc.ncep.noaa.gov/products/analysis_ monitoring/ensostuff/ensoyears.shtml). Biomass burning in these regions is characterized by a high percentage of peat fires, for which Akagi et al. ( 2011) give a much higher OCS emission factor of $1.2(2.21) \mathrm{g} \mathrm{kg}^{-1}$.

\subsubsection{The Asian monsoon anticyclone}

Figure 12 (top left) shows the OCS distribution observed by MIPAS during June to August at the $150 \mathrm{hPa}(\sim 13.0$ $14.3 \mathrm{~km}$ ) level, where enhanced OCS amounts also prevail over wide tropical and subtropical areas between about $30^{\circ} \mathrm{S}$ and $40^{\circ} \mathrm{N}$. Different to the $250 \mathrm{hPa}$ level, the OCS values
Table 3. Results of a correlation analysis between MIPAS OCS and simultaneously measured $\mathrm{HCN}$ for the latitude band between $50^{\circ} \mathrm{S}-0^{\circ} \mathrm{N}$ and the altitude range $10-14 \mathrm{~km}$ during southern hemispheric biomass burning seasons of subsequent years; $r$ : correlation coefficient; slope: slope of the regression line, the values in parentheses are the $1 \sigma$ uncertainties.

\begin{tabular}{lrr}
\hline Period & $r$ & slope \\
\hline Sep-Dec 2002 & 0.154 & $0.062(0.0015)$ \\
Sep-Dec 2003 & 0.017 & $0.014(0.0027)$ \\
Sep-Dec 2005 & 0.000 & $-0.001(0.0030)$ \\
Sep-Dec 2006 & 0.076 & $0.027(0.0019)$ \\
Sep-Dec 2007 & -0.08 & $-0.041(0.0018)$ \\
Sep-Dec 2008 & -0.09 & $-0.075(0.0024)$ \\
Sep-Dec 2009 & -0.02 & $-0.016(0.0021)$ \\
Sep-Dec 2010 & -0.06 & $-0.029(0.0016)$ \\
Sep-Dec 2011 & -0.02 & $-0.015(0.0018)$ \\
\hline
\end{tabular}

in the southern tropical and subtropical latitude band are generally of the same amount as those observed at northern low latitudes. The highest OCS amounts were observed above the Middle East, encircled by a region of enhanced OCS extending from the northern subtropical Atlantic over northern Africa and South Asia to the Chinese coast. This feature reflects the AMA, which regularly forms in boreal summer in the upper troposphere and is usually situated between northern Africa and eastern China. Enhanced OCS in this region is consistent with observation of high amounts 

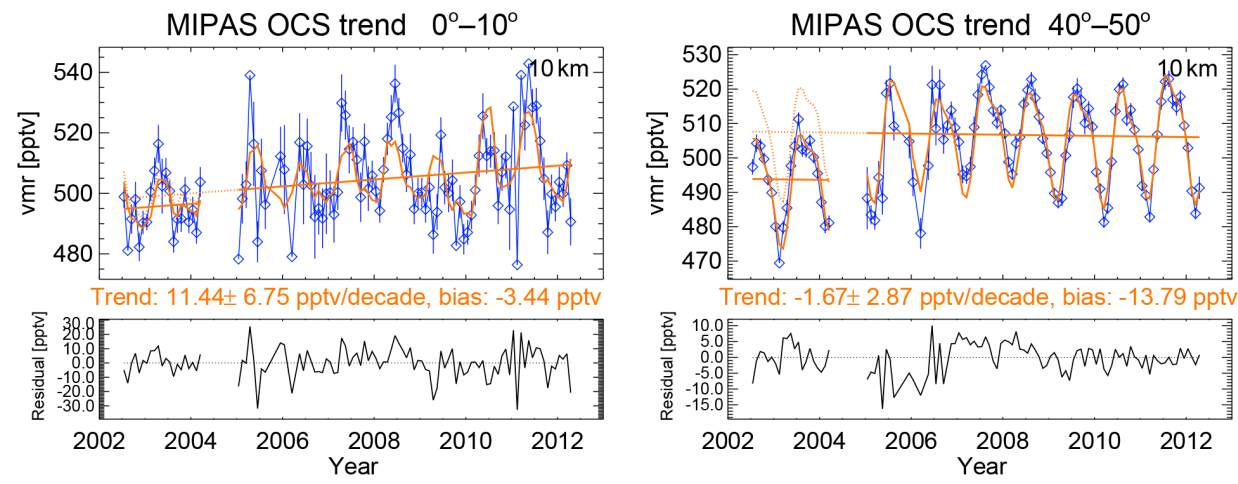

Figure 13. Trend analysis of MIPAS OCS measured at $10 \mathrm{~km}$ altitude in the latitude bands $0-10^{\circ} \mathrm{N}$ (left) and $40-50^{\circ} \mathrm{N}$ (right). The upper panels show monthly means of measured and fitted OCS (blue and red curves) and fitted linear trends (red lines). The lower panels show the residuals.

of other trace gases like CO (Funke et al., 2009) or HCN (Randel et al., 2010; Glatthor et al., 2015b), which are effectively transported upward in the region of the Asian summer monsoon and then accumulate in the AMA due to confinement by the strong anticyclonic circulation. A possible reason for the high amounts of OCS inside the AMA is strong release from the northern tropical Pacific and Indian Ocean. Additional potential sources are anthropogenic emissions of OCS, which according to Campbell et al. (2015) are currently concentrated in Asia. While CO or HCN in the AMA region are strongly enhanced, the OCS VMRs are not much higher than above the northern Pacific and above the whole southern tropics. This is due to different sources and the longer lifetime of OCS compared to the other species.

Instead of the coherent OCS depletion between Brazil and southern Africa observed at $250 \mathrm{hPa}$ there are three areas of reduced OCS at $150 \mathrm{hPa}$, situated above central Americanorthern South America, central Africa and north of Indonesia. The southern parts of the American and Indonesian depletions are probably caused by vegetative uptake, while the northern parts seem to be due to meridional transport around the upper tropospheric anticyclones discussed in Sect. 4.3.4. This assumption is based on comparison with the respective ozone distribution measured by MIPAS (Fig. 12, bottom left), which exhibits low tropospheric values in the tropics and considerably higher stratospheric values at mid- and high latitudes. There are two tongues of enhanced $\mathrm{O}_{3}$ extending south-westward towards Central America and towards the Philippines, which also reflect meridional transport and coincide with the northern parts of the OCS depletions. Due to subsidence in the Antarctic vortex, very low OCS amounts of 390-450 pptv were observed at southern high latitudes, while the values in the Arctic are around 490 pptv.

\subsubsection{Meridional transport in the UTLS region}

The OCS distribution observed during boreal summer at the $80 \mathrm{hPa}$ level ( 17.0-17.9 km) (Fig. 12, top right) also ex- hibits the highest values in the tropics and subtropics. However, at this pressure level the major part of the area of enhanced OCS is situated in the Southern Hemisphere. In the Northern Hemisphere there is a band of enhanced values extending from the tropical Atlantic to the Chinese coast, which reflects the upper end of the AMA including westward outflow. Another region of high OCS values is situated above the eastern Pacific. Directly south of the enhanced OCS amounts at the top of the AMA there is a large region of low values above South and South-East Asia, extending westward as far as western Africa in a small band. These low OCS amounts apparently originate from northern mid-latitudes and were transported southward and subsequently westward by the anticyclonic circulation at the edge of the AMA. Meridional transport around the AMA is corroborated by, e.g., the ozone distribution measured by MIPAS (bottom row), which in the UTLS region exhibits a tongue of enhanced values reaching from the western Pacific to South Asia and northern Africa. A similar structure has also been found in ozone data of the Atmospheric Infrared Sounder (AIRS) averaged over July and August 2003 (Randel and Park, 2006, Fig. 1d). Further, this transport process was modelled by, e.g., Ploeger et al. (2012) by back trajectory calculations. The major part of modelled southward transport into the tropical latitude band occurred during August to September at potential temperature levels of $420-450 \mathrm{~K}(\sim 16.5-18 \mathrm{~km})$, which is in good agreement with our observations.

A weaker, but similar feature of meridional OCS transport is also visible over Central America. The air masses with low OCS amounts detected in this area were obviously transported southward at the eastern side of the quasi-stationary anticyclone centred above the south-western United States. This feature has also been observed in airborne in situ $\mathrm{O}_{3}$ measurements performed between the south-eastern United States and Central America in July 2002 (Richard et al., 2003). Towards high latitudes the measured OCS amounts decrease strongly. 

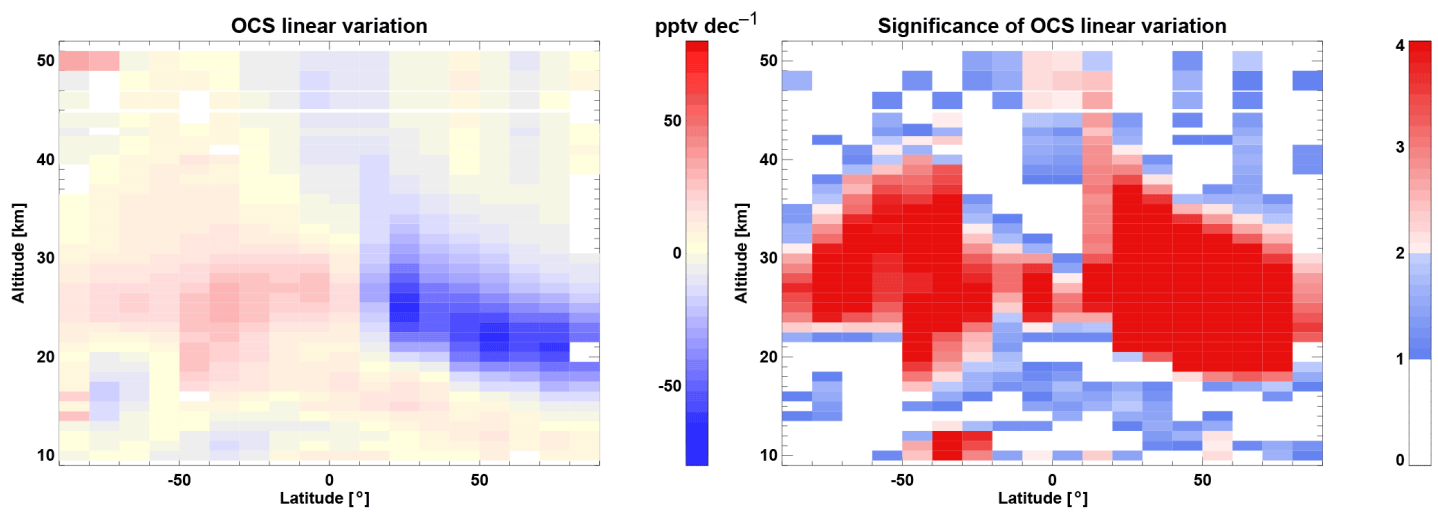

Figure 14. Left: decennial linear trend of monthly averaged OCS volume mixing ratios in $10^{\circ} \times 1 \mathrm{~km}$ latitude-altitude bins for the period 2002-2012. Right: significance of the bin-wise trends, estimated by division by the standard deviation from the respective regression analysis.

\subsection{Trends}

A dedicated trend analysis of MIPAS OCS was performed for $10^{\circ} \times 1 \mathrm{~km}$ latitude-altitude bins on the basis of monthly zonal averages. For each bin the analysis was carried out by fitting of regression functions consisting of a linear trend, 8 sine and cosine waves with periods between 3 and 24 months and of 2 terms describing the QBO to the time series of monthly averages (von Clarmann et al., 2010; Stiller et al., 2012). Figure 13 shows the measured OCS time series and the fitted regression curves in an exemplary manner for two bins at $10 \mathrm{~km}$ altitude. As outlined in Sect. 4.1, there is a discontinuity at or somewhat after the switch from the HR to the RR mode. This is taken into account by an offset as additional fit parameter, resulting in biases of 5 and $14 \mathrm{pptv}$ in the two examples, respectively. The whole set of fitted linear trends is shown in Fig. 14 (left) along with the respective significance estimates (right), which were calculated by division of the regression coefficients by their standard deviations. Values of 2 or larger characterize highly significant trends. Except for rather weak trends of about $+10 \mathrm{pptv} \mathrm{decade}^{-1}$ in the tropics and at $50-60^{\circ} \mathrm{N}\left(\sim 2 \%\right.$ decade $\left.^{-1}\right)$ as well as of -10 pptv decade $^{-1}\left(\sim-2 \%\right.$ decade $\left.^{-1}\right)$ in the southern subtropics and mid-latitudes, no significant temporal change was determined for the altitude of $10 \mathrm{~km}$. According to this result, tropospheric sources and sinks of OCS should be largely balanced. Thus, the significant positive trends obtained from ground-based FTIR measurements above the Jungfraujoch for the period 2002-2008 (Lejeune et al., 2017) and in the Southern Hemisphere for the period 2001-2014 (Kremser et al., 2015) cannot be confirmed (cf. Introduction).

Considerably stronger trends were calculated for the middle stratosphere. There is a large area of negative trends of up to -65 pptv decade ${ }^{-1}$ in the whole Northern Hemisphere, extending from 15 to $30 \mathrm{~km}$ in the Arctic and from 20 to $40 \mathrm{~km}$ at $10-20^{\circ} \mathrm{N}$. On the basis of a $2 \sigma$ confidence threshold, these trends are highly significant. In the Southern Hemisphere there is an area of somewhat weaker positive trends extending from 15 to $40 \mathrm{~km}$ at mid-latitudes and from about 20 to $30 \mathrm{~km}$ in the tropics and in the Antarctic. These trends are also highly significant. A possible reason for these trends is a change in the global circulation, e.g. in the strength or latitudinal centring of the Brewer-Dobson circulation, during the years of MIPAS operation. Similar structures were detected in trend analyses of, e.g., MIPAS CFC-11 (Kellmann et al., 2012) or ozone (Eckert et al., 2014).

\section{Conclusions}

We have presented a long-term spaceborne global data set of MIPAS OCS covering the period from June 2002 to April 2012, providing information on one of the major sources of atmospheric sulfur. This data set can be used to constrain future model runs and thus can help to improve the understanding of the global sulfur cycle. In fact, a paper on this topic, also using MIPAS OCS and $\mathrm{SO}_{2}$ data, is in preparation (Deshler, personal communication, 2014). The measurements were compared with balloon profiles, ACE-FTS data and with ground-based measurements of the NOAA ESRL network. No systematic bias was detected with respect to balloon profiles, but MIPAS OCS amounts at $13-16 \mathrm{~km}$ altitude are up to 100 pptv higher than coincident ACE-FTS values. The reason for this discrepancy is an open issue.

Time series of MIPAS OCS data show annual variations in the troposphere and a rather biennial cycle in the tropical stratosphere. Interannual variations are only moderate, indicating a closed budget of tropospheric OCS sources and sinks. This is confirmed by a dedicated trend analysis, which resulted in no significant trends in the upper troposphere. In the stratosphere, a large area of strong negative trends was detected in the Northern Hemisphere, accompanied by an area of positive trends in the Southern Hemisphere. This pattern indicates a change in the Brewer-Dobson circulation.

Zonal averages of tropospheric OCS amounts observed by MIPAS range from below $470 \mathrm{pptv}$ at high latitudes to 
540 pptv in the tropics and at northern mid-latitudes, but show only moderate seasonal variations. These features are in reasonably good agreement with EMAC model simulations. Interhemispheric differences are small, e.g. the ratio between northern and southern hemispheric annual tropospheric averages is 1.01 only. At $10 \mathrm{~km}$ altitude, zonally averaged seasonal variations have an amplitude of 30-35 pptv in the Northern and 15-20 pptv in the Southern Hemisphere. The variations at northern mid- and high-latitude surface stations of the NOAA ESRL network are much higher, namely up to $110 \mathrm{pptv}$. This is due to the strong seasonal variation of vegetation uptake influencing these measurements. Obviously this signal is considerably weakened in zonal means at $10 \mathrm{~km}$ altitude. In the Southern Hemisphere the amplitudes observed at the surface stations and at $10 \mathrm{~km}$ altitude are lower and in better agreement.

At northern hemispheric low latitudes, maximum MIPAS OCS amounts at $10 \mathrm{~km}$ were measured around June and minima in fall and winter, which agrees fairly well with the seasonality of surface observations. At northern mid- and high latitudes, maxima were observed in August and October and minima in March and April. These variations are temporally delayed by $4-6$ months compared to the ground-based cycles, where the OCS decrease starts in May and June. A certain portion of this large temporal shift can be due to weaker convection than at tropical latitudes. However, towards higher latitudes subsidence of OCS-poor air in the polar vortex and subsequent recovery until late summer becomes more and more dominant. In the Southern Hemisphere there are temporal shifts of 3-4 months between the variations observed at the ground and at $10 \mathrm{~km}$ altitude at all latitudes, at least at mid- and high latitudes, for the same reasons as in the Northern Hemisphere.

The stratospheric OCS distribution is similar to that of other trace gases like $\mathrm{N}_{2} \mathrm{O}$ or CFC-11. Due to broad upwelling the highest stratospheric OCS values were observed in the lower tropical stratosphere. Towards higher altitudes and latitudes stratospheric OCS exhibits a considerable decrease. Low stratospheric OCS amounts at high latitudes during polar winter indicate subsidence of air masses inside the polar vortices.

Horizontal distributions of upper tropospheric OCS exhibit enhanced OCS amounts at low latitudes, most pronounced during boreal summer above the western Pacific and the Indian Ocean. Apparently, these enhancements are mainly caused by oceanic release. This conclusion is supported by various budget estimations, but Blake et al. (2004) and Lennartz et al. (2017) assume a larger contribution of anthropogenic Asian emissions. A striking feature is a region of low OCS amounts between Brazil and southern Africa, which is most distinct during austral summer. This depletion obviously is caused by vegetative uptake in the tropical forests. Typical features of biomass burning like the southern hemispheric plume are not visible in MIPAS data, indicating that biomass burning is only a minor source of atmo- spheric OCS. The enhanced amounts of OCS observed in the AMA instead result from oceanic and industrial emissions. The OCS distributions at $80 \mathrm{hPa}$ altitude reflect equatorward transport of mid-latitude air masses around summer anticyclones prevailing in the upper troposphere. This process is most distinct at the western and southern edge of the AMA, but is also observable in the western hemisphere, where air masses deleted in OCS are carried towards Central America.

\section{Data availability}

MIPAS data are available from http://www.imk-asf.kit. edu/english/308.php (upon registration) and from the corresponding author (Norbert.Glatthor@kit.edu). The ACE-FTS data used in this study can be obtained upon registration via the website https://databace.scisat.ca or from Kaley A. Walker (kaley.walker@utoronto.ca.). MkIV balloon data are available at the website http: //mark4sun.jpl.nasa.gov/m4data.html. SPIRALE data are available from Gisèle Krysztofiak (gisele.krysztofiak@cnrsorleans.fr). EMAC OCS-data are available from Gisèle Krysztofiak (gisele.krysztofiak@cnrs-orleans.fr) or from the corresponding author (Norbert.Glatthor@kit.edu).

Competing interests. The authors declare that they have no conflict of interest.

Acknowledgements. Part of this work has been funded by the Federal Ministry for Economic Affairs and Energy under contract number 50EE1547. The authors would like to thank the European Space Agency for giving access to MIPAS level-1 data. Meteorological analysis data have been provided by ECMWF. We acknowledge support by the Deutsche Forschungsgemeinschaft and Open-Access Publishing Fund of the Karlsruhe Institute of Technology. The Atmospheric Chemistry Experiment (ACE), also known as SCISAT, is a Canadian-led mission mainly supported by the Canadian Space Agency and the Natural Sciences and Engineering Research Council of Canada. We acknowledge the provision of MkIV and SPIRALE balloon profiles. OCS flask data were provided from the Global Monitoring Division of the Nationals Oceanic and Atmospheric Administration's Earth System Research Laboratory (NOAA ESRL/GMD).

The article processing charges for this open-access publication were covered by a Research Centre of the Helmholtz Association.

Edited by: M. von Hobe

Reviewed by: two anonymous referees 


\section{References}

Adams, D. F., Farwell, S. O., Robinson, E., Pack, M. R., and Bamesberger, W. L.: Biogenic Sulphur Source Strengths, Environ. Sci. Technol., 15, 1493-1498, 1981.

Akagi, S. K., Yokelson, R. J., Wiedinmyer, C., Alvarado, M. J., Reid, J. S., Karl, T., Crounse, J. D., and Wennberg, P. O.: Emission factors for open and domestic biomass burning for use in atmospheric models, Atmos. Chem. Phys., 11, 4039-4072, doi:10.5194/acp-11-4039-2011, 2011.

Andreae, M. O.: Ocean-atmosphere interactions in the global biogeochemical sulfur cycle, Mar. Chem., 30, 1-29, 1990.

Barkley, M. P., Palmer, P. I., Boone, C. D., Bernath, P. F., and Suntharalingam, P.: Global distributions of carbonyl sulfide in the upper troposphere and stratosphere, Geophys. Res. Lett., 35, L14810, doi:10.1029/2008GL034270, 2008.

Bernath, P. F., McElroy, C. T., Abrams, M. C., Boone, C. D., Butler, M., Camy-Peyret, C., Carleer, M., Clerbaux, C., Coheur, P.F., Colin, R., DeCola, P., De Mazière, M., Drummond, J. R., Dufour, D., Evans, W. F. J, Fast, H., Fussen, D., Gilbert, K., Jennings, D. E., Llewellyn, E. J., Lowe, R. P., Mahieu, E., McConnell, J. C., McHugh, M., McLeod, S. D., Michaud, R., Midwinter, C., Nassar, R., Nichitiu, F., Nowlan, C., Rinsland, C. P., Rochon, Y. J., Rowlands, N., Semeniuk, K., Simon, P., Skelton, R., Sloan, J. J., Soucy, M.-A., Strong, K., Tremblay, P., Turnbull, D., Walker, K. A., Walkty, I., Wardle, D. A., Wehrle, V., Zander, R., and Zou, J.: Atmospheric Chemistry Experiment (ACE): Mission overview, Geophys. Res. Lett., 32, L15S01, doi:10.1029/2005GL022386, 2005.

Berry, J., Wolf, A., Campbell, J. E., Baker, I., Blake, N., Blake, D., Denning, A. S., Kawa, S. R., Montzka, S. A., Seibt, U., Stimler, K., Yakir, D., and Zhu, Z.: A coupled model of the global cycles of carbonyl sulfide and $\mathrm{CO}_{2}$ : A possible new window on the carbon cycle, J. Geophys. Res.-Biogeo., 118, 842-852, doi:10.1002/jgrg.20068, 2013.

Blake, N. J., Campbell, J. E., Vay, S. A., Fuelberg, H. E., Huey, L. G., Sachse, G., Meinardi, S., Beyersdorf, A., Baker, A., Barletta, B., Midyett, J., Doezema, L., Kamboures, M., McAdams, J., Novak, B., Rowland, F. S., and Blake, D. R.: Carbonyl sulfide (OCS): Large-scale distributions over North America during INTEX-NA and relationship to $\mathrm{CO}_{2}$, J. Geophys. Res., 113, D09S90, doi:10.1029/2007JD009163, 2008.

Boone, C. D., Nassar, R., Walker, K. A., Rochon, Y., McLeod, S. D., Rinsland, C. P., and Bernath, P. F.: Retrievals for the atmospheric chemistry experiment Fourier-transform spectrometer, Appl. Optics, 44, 7218-7231, 2005.

Boone, C. D., Walker, K. A., and Bernath, P. F.: Version 3 Retrievals for the Atmospheric Chemistry Experiment Fourier Transform Spectrometer (ACE-FTS), in: The Atmospheric Chemistry Experiment ACE at 10: A Solar Occultation Anthology, edited by: Bernath, P. F., A. Deepak Publishing 2013, Hampton, Virginia, USA, 103-127, 2013.

Brühl, C., Lelieveld, J., Crutzen, P. J., and Tost, H.: The role of carbonyl sulphide as a source of stratospheric sulphate aerosol and its impact on climate, Atmos. Chem. Phys., 12, 1239-1253, doi:10.5194/acp-12-1239-2012, 2012.

Brühl, C., Lelieveld, J., Tost, H., Höpfner, M., and Glatthor, N.: Stratospheric sulfur and its implications for radiative forcing simulated by the chemistry climate model EMAC, J. Geophys. Res.Atmos., 120, 2103-2118, doi:10.1002/2014JD022430, 2015.
Burgess, A. B., Grainger, R. G., and Dudhia, A.: Progress in the Retrieval of Sulphur Species from MIPAS, Proceedings of the 2004 Envisat and ERS Symposium (ESA SP-572), 2004.

Campbell, J. E., Whelan, M. E., Seibt, U., Smith, S. J, Berry, J. A., and Hilton T. W.: Atmospheric carbonyl sulfide sources from anthropogenic activity: Implications for carbon cycle constraints, Geophys. Res. Lett., 42, 3004-3010, doi:10.1002/2015GL063445, 2015.

Chin, M. and Davis, D. D.: Global sources and sinks of OCS and $\mathrm{CS}_{2}$ and their distributions, Global Biogeochem. Cy., 7, 321337, 1993.

Coheur, P.-F., Herbin, H., Clerbaux, C., Hurtmans, D., Wespes, C., Carleer, M., Turquety, S., Rinsland, C. P., Remedios, J., Hauglustaine, D., Boone, C. D., and Bernath, P. F.: ACE-FTS observation of a young biomass burning plume: first reported measurements of $\mathrm{C}_{2} \mathrm{H}_{4}, \mathrm{C}_{3} \mathrm{H}_{6} \mathrm{O}, \mathrm{H}_{2} \mathrm{CO}$ and PAN by infrared occultation from space, Atmos. Chem. Phys., 7, 5437-5446, doi:10.5194/acp-75437-2007, 2007.

Crutzen, P. J.: The possible importance of CSO for the sulphate layer of the stratosphere, Geophys. Res. Lett., 3, 73-76, 1976.

Eckert, E., von Clarmann, T., Kiefer, M., Stiller, G. P., Lossow, S., Glatthor, N., Degenstein, D. A., Froidevaux, L., GodinBeekmann, S., Leblanc, T., McDermid, S., Pastel, M., Steinbrecht, W., Swart, D. P. J., Walker, K. A., and Bernath, P. F.: Drift-corrected trends and periodic variations in MIPAS IMK/IAA ozone measurements, Atmos. Chem. Phys., 14, 25712589, doi:10.5194/acp-14-2571-2014, 2014.

Edwards, D. P., Emmons, L. K., Gille, J. C., Chu, A., Attié, J.L., Giglio, L., Wood, S. W., Haywood, J., Deeter, M. N., Massie, S. T., Ziskin, D. C., and Drummond, J. R.: Satelliteobserved pollution from Southern Hemisphere biomass burning, J. Geophys. Res., 111, D14312, doi:10.1029/2005JD006655, 2006.

Eriksson, E.: The yearly circulation of chloride and sulfur in nature; meteorological, geochemical and pedological implicationsII, Tellus, 12, 63-109, 1960.

European Space Agency: Envisat, MIPAS An instrument for atmospheric chemistry and climate research, ESA Publications Division, ESTEC, P.O. Box 299, 2200 AG Noordwijk, The Netherlands, SP-1229, 2000.

Farmer, C. B., Raper, O. F., and O'Callaghan, F. G.: Final report on the first flight of the ATMOS instrument during the Spacelab 3 mission, 29 April-6 May 1985, JPL Publ., Jet Propulsion Laboratory, 87-32, 1987.

Fischer, H., Birk, M., Blom, C., Carli, B., Carlotti, M., von Clarmann, T., Delbouille, L., Dudhia, A., Ehhalt, D., Endemann, M., Flaud, J. M., Gessner, R., Kleinert, A., Koopman, R., Langen, J., López-Puertas, M., Mosner, P., Nett, H., Oelhaf, H., Perron, G., Remedios, J., Ridolfi, M., Stiller, G., and Zander, R.: MIPAS: an instrument for atmospheric and climate research, Atmos. Chem. Phys., 8, 2151-2188, doi:10.5194/acp-8-2151-2008, 2008.

Flaud, J.-M., Piccolo, C., Carli, B., Perrin, A., Coudert, L. H., Teffo, J. L., and Brown, L. R.: Molecular line parameters for the MIPAS (Michelson Interferometer for Passive Atmospheric Sounding) experiment, Atmospheric and Oceanic Optics, 16, 172-182, 2003.

Friend, J. P.: The Global Sulfur Cycle, in: Chemistry of the Lower Atmosphere, edited by: Rasool, S. I., Plenum Press, New York, 177-201, 1973. 
Funke, B., López-Puertas, M., García-Comas, M., Stiller, G. P., von Clarmann, T., Höpfner, M., Glatthor, N., Grabowski, U., Kellmann, S., and Linden, A.: Carbon monoxide distributions from the upper troposphere to the mesosphere inferred from $4.7 \mu \mathrm{m}$ non-local thermal equilibrium emissions measured by MIPAS on Envisat, Atmos. Chem. Phys., 9, 2387-2411, doi:10.5194/acp-92387-2009, 2009.

Glatthor, N., Höpfner, M., Baker, I. T. , Berry, J., Campbell, J. E., Kawa, S. R., Krysztofiak, G., Leyser, A., Sinnhuber, B.-M., Stiller, G. P., Stinecipher, J., and von Clarmann, T.: Tropical sources and sinks of carbonyl sulfide observed from space, Geophys. Res. Lett., 42, 10082-10090, doi:10.1002/2015GL066293, 2015a.

Glatthor, N., Höpfner, M., Stiller, G. P., von Clarmann, T., Funke, B., Lossow, S., Eckert, E., Grabowski, U., Kellmann, S., Linden, A., A. Walker, K., and Wiegele, A.: Seasonal and interannual variations in $\mathrm{HCN}$ amounts in the upper troposphere and lower stratosphere observed by MIPAS, Atmos. Chem. Phys., 15, 563582, doi:10.5194/acp-15-563-2015, 2015b.

Griffith, D. W. T., Jones, N. B., and Matthews, W. A.: Interhemispheric ratios and annual cycle of carbonyl sulfide (OCS) total column from ground-based solar FTIR spectra, J. Geophys. Res., 103, 8447-8454, 1998.

Hanst, P. L., Spiller, L. L., Watts, D. M., Spence, J. W., and Miller M. F.: Infra-red measurements of fluorocarbons, carbon tetrachloride, carbonyl sulphide and other atmospheric trace gases, JAPCA J. Air Waste Ma., 25, 1220-1226, 1975.

Höpfner, M., von Clarmann, T., Fischer, H., Glatthor, N., Grabowski, U., Kellmann, S., Kiefer, M., Linden, A., Mengistu Tsidu, G., Milz, M., Steck, T., Stiller, G. P., Wang, D.-Y., and Funke, B.: First spaceborne observations of Antarctic stratospheric $\mathrm{ClONO}_{2}$ recovery: Austral spring 2002, J. Geophys. Res., 109, D11308, doi:10.1029/2004JD004609, 2004.

Hughes, R., Boone, C., and Bernath, P.: ACE-FTS SpectroscopyVersion 3.5, Atmospheric Chemistry Experiment, Science Operations Center, Department of Chemistry, University of Waterloo, Waterloo, Ontario, N2L 3G1, Document Number: ACE-SOC0027, Issue: 1, Revision A, 2016.

Jöckel, P., Tost, H., Pozzer, A., Brühl, C., Buchholz, J., Ganzeveld, L., Hoor, P., Kerkweg, A., Lawrence, M. G., Sander, R., Steil, B., Stiller, G., Tanarhte, M., Taraborrelli, D., van Aardenne, J., and Lelieveld, J.: The atmospheric chemistry general circulation model ECHAM5/MESSy1: consistent simulation of ozone from the surface to the mesosphere, Atmos. Chem. Phys., 6, 50675104, doi:10.5194/acp-6-5067-2006, 2006.

Jöckel, P., Kerkweg, A., Pozzer, A., Sander, R., Tost, H., Riede, H., Baumgaertner, A., Gromov, S., and Kern, B.: Development cycle 2 of the Modular Earth Submodel System (MESSy2), Geosci. Model Dev., 3, 717-752, doi:10.5194/gmd-3-717-2010, 2010.

Junge, C. E.: Air Chemistry and Radioactivity, Academic Press, New York, 1963.

Kellmann, S., von Clarmann, T., Stiller, G. P., Eckert, E., Glatthor, N., Höpfner, M., Kiefer, M., Orphal, J., Funke, B., Grabowski, U., Linden, A., Dutton, G. S., and Elkins, J. W.: Global CFC-11 $\left(\mathrm{CCl}_{3} \mathrm{~F}\right)$ and CFC-12 $\left(\mathrm{CCl}_{2} \mathrm{~F}_{2}\right)$ Measurements with the Michelson Interferometer for Passive Atmospheric Sounding (MIPAS): retrieval, climatologies and trends, Atmos. Chem. Phys., 12, 11857-11875, doi:10.5194/acp-12-11857-2012, 2012.
Kellogg, W. W., Cadle, R. D., Allen, E. R., Lazrus, A. L., and Martell, E. A.: The Sulfur Cycle, Science, 175, 587-596, 1972.

Kettle, A. J., Kuhn, U., von Hobe, M., Kesselmeier, J., and Andreae, M. O.: Global budget of atmospheric carbonyl sulfide: Temporal and spatial variations of the dominant sources and sinks, J. Geophys. Res., 107, 4658, doi:10.1029/2002JD002187, 2002.

Kremser, S., Jones, N. B., Palm, M., Lejeune, B., Wang, Y., Smale, D., and Deutscher, N. M.: Positive trends in Southern Hemisphere carbonyl sulfide, Geophys. Res. Lett., 42, 9473-9480, doi:10.1002/2015GL065879, 2015.

Kremser, S., Thomason, L. W., von Hobe, M., Hermann, M., Deshler, T., Timmreck, C., Toohey, M., Stenke, A., Schwarz, J. P., Weigel, R., Fueglistaler, S., Prata, F. J., Vernier, J.-P., Schlager, H., Barnes, J. E., Antuña-Marrero, J.-C., Fairlie, D., Palm, M., Mahieu, E., Notholt, J., Rex, M., Bingen, C., Vanhellemont, F., Bourassa, A., Plane, J. M. C., Klocke, D., Carn, S. A., Clarisse, L., Trickl, T., Neely, R., James, A. D., Rieger, L., Wilson, J. C., and Meland, B.: Stratospheric aerosol-Observations, processes, and impact on climate, Rev. Geophys., 54, 278-335, doi:10.1002/2015RG000511, 2016.

Krysztofiak, G., Té, Y. V., Catoire, V., Berthet, G., Toon, G. C., Jégou, F., Jeseck, P., and Robert, C.: Carbonyl sulphide (OCS) variability with latitude in the atmosphere, Atmos. Ocean, QOS special issue, 53, 1-13, doi:10.1080/07055900.2013.876609, 2014.

Kuai, L., Worden, J., Kulawik, S. S., Montzka, S. A., and Liu, J.: Characterization of Aura TES carbonyl sulfide retrievals over ocean, Atmos. Meas. Tech., 7, 163-172, doi:10.5194/amt-7-1632014, 2014.

Kuhn, U., Ammann, C., Wolf, A., Meixner, F. X., Andreae, M. O., and Kesselmeier, J.: Carbonyl sulfide exchange on an ecosystem scale: soil represents a dominant sink for atmospheric OCS, Atmos. Environ., 33, 995-1008, 1999.

Launois, T., Belviso, S., Bopp, L., Fichot, C. G., and Peylin, P.: A new model for the global biogeochemical cycle of carbonyl sulfide - Part 1: Assessment of direct marine emissions with an oceanic general circulation and biogeochemistry model, Atmos. Chem. Phys., 15, 2295-2312, doi:10.5194/acp-15-22952015, 2015.

Lejeune, B., Mahieu, E., Vollmer, M. K., Reimann, S., Bernath, P. F., Boone, C. D., Walker, K. A., and Servais, C.: Optimized approach to retrieve information on atmospheric carbonyl sulfide (OCS) above the Jungfraujoch station and change in its abundance since 1995, J. Quant. Spectrosc. Ra., 186, 81-95, doi:10.1016/j.jqsrt.2016.06.001, 2017.

Lennartz, S. T., Marandino, C. A., von Hobe, M., Cortes, P., Quack, B., Simo, R., Booge, D., Pozzer, A., Steinhoff, T., ArevaloMartinez, D. L., Kloss, C., Bracher, A., Röttgers, R., Atlas, E., and Krüger, K.: Direct oceanic emissions unlikely to account for the missing source of atmospheric carbonyl sulfide, Atmos. Chem. Phys., 17, 385-402, doi:10.5194/acp-17-385-2017, 2017.

Li, Q., Jacob, D. J., Yantosca, R. M., Heald, C. L., Singh, H. B., Koike, M., Zhao. Y., Sachse, G. W., and Streets, D. G.: A global three-dimensional model analysis of the atmospheric budgets of $\mathrm{HCN}$ and $\mathrm{CH}_{3} \mathrm{CN}$ : constraints from aircraft and ground measurements, J. Geophys. Res., 108, 8827, doi:10.1029/2002JD003075, 2003.

Mahieu, E., Zander, R., Demoulin, P., Duchatelet, P., Servais, C., Rinsland, C. P., and De Mazière, M.: Recent evolution of atmospheric OCS above the Jungfraujoch station: Implications 
for the stratospheric aerosol layer, in: Proceedings of "Atmospheric Spectroscopy Applications, ASA Reims 2005", Reims, 6-8 September 2005, 235-238, 2005.

Montzka, S. A., Aydin, M., Battle, M., Butler, J. H., Saltzman, E. S., Hall, B. D., Clarke, A. D., Mondeel, D., and Elkins, J. W.: A 350-year atmospheric history for carbonyl sulfide inferred from Antarctic firn air and air trapped in ice, J. Geophys. Res., 109, D22302, doi:10.1029/2004JD004686, 2004.

Montzka, S. A., Calvert, P., Hall, B. D., Elkins, J. W., Conway, T. J., Tans, P. P., and Sweeney, C.: On the global distribution, seasonality, and budget of atmospheric carbonyl sulfide (COS) and some similarities to $\mathrm{CO}_{2}$, J. Geophys. Res., 112, D09302, doi:10.1029/2006JD007665, 2007.

Moreau, G., Robert, C., Catoire, V., Chartier, M., Camy-Peyret, C., Huret, N., Pirre, M., Pomathiod, L., and Chalumeau, G.: A multispecies in situ balloon-borne experiment with six tunable diode laser spectrometers, Appl. Optics, 44, 5972-5989, 2005.

Nett, H., Perron, G., Sanchez, M., Burgess, A., and Mossner, P.: MIPAS inflight calibration and processor validation, in ENVISAT Calibration Review - Proc. of the European Workshop, 9-13 September 2002, ESTEC, Noordwijk, The Netherlands, CDROM, vol. SP-520, edited by: Sawaya-Lacoste, H., ESA Publications Division, ESTEC, Postbus 299, 2200 AG Noordwijk, The Netherlands, 2002.

Nguyen, B. C., Mihalopoulos, N., Putaud, J. P., and Bonsang, B.: Carbonyl Sulfide Emissions from Biomass Burning in the Tropics, J. Atmos. Chem., 22, 55-65, 1995.

Notholt, J., Kuang, Z., Rinsland, C. P., Toon, G. C., Rex, M., Jones, N., Albrecht, T., Deckelmann, H., Krieg, J., Weinzierl, C., Bingemer, H., Weller, R., and Schrems, O.: Enhanced Upper Tropical Tropospheric COS: Impact on the Stratospheric Aerosol Layer, Science, 300, 307, doi:10.1126/science.1080320, 2003.

Ploeger, F., Konopka, P., Müller, R., Fueglistaler, S., Schmidt, T., Manners, J. C., Grooß, J.-U., Günther, G., and Forster, P. M.: Horizontal transport affecting trace gas seasonality in the Tropical Tropopause Layer (TTL), J. Geophys. Res., 117, D09303, doi:10.1029/2011JD017267, 2012.

Randel, W. J. and Park, M.: Deep convective influence on the Asian summer monsoon anticyclone and associated tracer variability observed with Atmospheric Infrared Sounder (AIRS) J. Geophys. Res., 111, D12314, doi:10.1029/2005JD006490, 2006.

Randel, W. J., Park, M., Emmons, L., Kinnison, D., Bernath, P., Walker, K. A., Boone, C., and Pumphrey, H.: Asian Monsoon transport of pollution to the stratosphere, Science, 328, 611-613, doi:10.1126/science.1182274, 2010.

Remedios, J. J., Leigh, R. J., Waterfall, A. M., Moore, D. P., Sembhi, H., Parkes, I., Greenhough, J., Chipperfield, M. P., and Hauglustaine, D.: MIPAS reference atmospheres and comparisons to V4.61/V4.62 MIPAS level 2 geophysical data sets, Atmos. Chem. Phys. Discuss., 7, 9973-10017, doi:10.5194/acpd-79973-2007, 2007.

Richard, E. C., Aikin, K. C., Ray, E. A., Rosenlof, K. H., Thompson, T. L., Weinheimer, A., Montzka, D., Knapp, D., Ridley, B., and Gettelman, A.: Large-scale equatorward transport of ozone in the subtropical lower stratosphere, J. Geophys. Res., 108, 4714, doi:10.1029/2003JD003884, 2003.

Rinsland, C. P., Goldman, A., Mahieu, E., Zander, R., Notholt, J., Jones, N. B., Griffith, D. W. T., Stephen, T. M., and Chiou, L. S.: Ground-based infrared spectroscopic measurements of carbonyl sulfide: Free tropospheric trends from a 24-year time series of solar absorption measurements, J. Geophys. Res., 107, 4657, doi:10.1029/2002JD002522, 2002.

Robinson, E. and Robbins, R. C.: Sources, Abundance, and Fate of Gaseous Atmospheric Pollutants, SRI Project Report PR-6755, prepared for American Petroleum Institute, N.Y., 123 pp., 1968.

Roeckner, E., Brokopf, R., Esch, M., Giorgetta, M., Hagemann, S., Kornblueh, L., Manzini, E., Schlese, U., and Schulzweida, U.: Sensitivity of simulated climate to horizontal and vertical resolution in the ECHAM5 atmosphere model, J. Climate, 19, 37713791, 2006.

Rothman, L. S., Jacquemart, D., Barbe, A., Benner D. C., Birk, M., Brown, L. R., Carleer, M. R., Chackerian Jr., C., Chance, K., Coudert, L. H., Dana, V., Devi, V. M., Flaud, J.-M., Gamache, R. R., Goldman, A., Hartmann, J.-M., Jucks, K. W., Maki, A. G., Mandin J.-Y., Massie, S. T., Orphal, J., Perrin, A., Rinsland, C. P., Smith, M. A. H., Tennyson, J., Tolchenov, R. N., Toth, R. A., Vander Auwera, J., Varanasi, P., and Wagner, G.: The HITRAN 2004 molecular spectroscopic database, J. Quant. Spectrosc. Ra., 96, 193-204, 2005.

Rothman, L. S., Gordon, I. E., Barbe, A., Chris Benner, D., Bernath, P. F., Birk, M., Boudon, V., Brown, L. R., Campargue, A., Champion, J.-P., Chance, K., Coudert, L. H., Dana, V., Devi, V. M., Fally, S., Flaud, J.-M., Gamache, R. R., Goldman, A., Jacquemart, D., Kleiner, I., Lacome, N., Lafferty, W. J., Mandin, J.-Y, Massie, S. T., Mikhailenko, S. N., Miller, C. E., Moazzen-Ahmadi, N., Naumenko, O. V., Nikitin, A. V., Orphal, J., Perevalov, V. I., Perrin, A., Predoi-Cross, A., Rinsland, C. P., Rotger, M., S`imečková, M., Smith, M. A. H., Sung, K., Tashkun, S. A., Tennyson, J., Toth, R. A., Vandaele, A. C., and Vander Auwera, J.: The HITRAN 2008 molecular spectroscopic database, J. Quant. Spectrosc. Ra., 110, 533572, doi:10.1016/j.jqsrt.2009.02.013, 2009.

Rothman, L. S., Gordon, I. E., Babikov, Y., Barbe, A., Chris Benner, D., Bernath, P. F., Birk, M. Bizzocchi, L., Boudon, V., Brown, L. R., Campargue, A., Chance, K., Cohen, E. A., Coudert, L. H., Devi, V. M., Drouin, B. J., Fayt, A., Flaud, J.M. Gamache, R. R., Harrison, J. J., Hartmann, J.-M., Hill, C., Hodges, J. T., Jacquemart, D., Jolly, A., Lamouroux, J., Le Roy, R. J., Li, G., Long, D. A., Lyulin, O. M., Mackie, C. J., Massie, S. T., Mikhailenko, S., Müller,. H. S. P., Naumenko, O. V., Nikitin, A. V., Orphal, J., Perevalov, V., Perrin, A., Polovtseva, E. R., Richard, C., Smith, M. A. H., Starikova, E., Sung, K., Tashkun, S., Tennyson, J., Toon, G. C., Tyuterev, Vl. G. and Wagner, G.: The HITRAN 2012 molecular spectroscopic database, J. Quant. Spectrosc. Ra., 130, 4-50, doi:10.1016/j.jqsrt.2013.07.002, 2013.

Sandalls, F. J. and Penkett, S. A.: Measurements of carbonyl sulphide and carbon disulphide in the atmosphere, Atmos. Environ. 11, 197-199, 1977.

Sandoval-Soto, L., Stanimirov, M., von Hobe, M., Schmitt, V., Valdes, J., Wild, A., and Kesselmeier, J.: Global uptake of carbonyl sulfide (COS) by terrestrial vegetation: Estimates corrected by deposition velocities normalized to the uptake of carbon dioxide $\left(\mathrm{CO}_{2}\right)$, Biogeosciences, 2, 125-132, doi:10.5194/bg-2-1252005, 2005.

Singh, H. B., Salas, L., Herlth, D., Kolyer, R., Czech, E., Viezee, W., Li, Q., Jacob, D. J., Blake, D., Sachse, G., Harward, C. N., Fuelberg, H., Kiley, C. M., Zhao, Y., and Kondo, Y.: 
In situ measurements of $\mathrm{HCN}$ and $\mathrm{CH}_{3} \mathrm{CN}$ over the Pacific Ocean: sources, sinks and budgets, J. Geophys. Res., 108, 8795, doi:10.1029/2002JD003006, 2003.

Steck, T.: Methods for determining regularization for atmospheric retrieval problems, Appl. Optics, 41, 1788-1797, 2002.

Stiller, G. P. (Ed.): The Karlsruhe Optimized and Precise Radiative transfer Algorithm (KOPRA), Institut für Meteorologie und Klimaforschung, Forschungszentrum Karlsruhe GmbH, 2000.

Stiller, G. P., von Clarmann, T., Haenel, F., Funke, B., Glatthor, N., Grabowski, U., Kellmann, S., Kiefer, M., Linden, A., Lossow, S., and López-Puertas, M.: Observed temporal evolution of global mean age of stratospheric air for the 2002 to 2010 period, Atmos. Chem. Phys., 12, 3311-3331, doi:10.5194/acp-12-33112012, 2012.

Suntharalingam, P., Kettle, A. J., Montzka, M., and Jacob, D. J.: Global 3-D model analysis of the seasonal cycle of atmospheric carbonyl sulfide: Implications for terrestrial vegetation uptake, Geophys. Res. Lett., 35, L19801, doi:10.1029/2008GL034332, 2008.

Toon, G. C.: The JPL MkIV Interferometer, Opt. Photonics News, 2, 19-21, doi:10.1364/OPN.2.10.000019, 1991.

Velazco, V. A., Toon, G. C., Blavier, J.-F. L., Kleinböhl, A., Manney, G. L., Daffer, W. H., Bernath, P. F., Walker, K. A., and Boone, C.: Validation of the Atmospheric Chemistry Experiment by noncoincident MkIV balloon profiles, J. Geophys. Res., 116, D06306, doi:10.1029/2010JD014928, 2011.

Vincent, R. A. and Duhdia, A.: Fast retrievals of tropospheric carbonyl sulphide with IASI, Atmos. Chem. Phys. Discuss., doi:10.5194/acp-2016-794, in review, 2016.

von Clarmann, T., Fischer, H., Funke, B., Glatthor, N., Grabowski, U., Höpfner, M., Kellmann, S., Kiefer, M., Linden, A., Mengistu Tsidu, G., Milz, M., Steck, T., Stiller, G. P., Wang, D.-Y., GilLópez, S., and López-Puertas, M.: Retrieval of temperature and tangent altitude pointing from limb emission spectra recorded from space by the Michelson Interferometer for Passive Atmospheric Sounding (MIPAS), J. Geophys. Res., 108, 4736, doi:10.1029/2003JD003602, 2003. von Clarmann, T., Glatthor, N., Koukouli, M. E., Stiller, G. P., Funke, B., Grabowski, U., Höpfner, M., Kellmann, S., Linden, A., Milz, M., Steck, T., and Fischer, H.: MIPAS measurements of upper tropospheric $\mathrm{C}_{2} \mathrm{H}_{6}$ and $\mathrm{O}_{3}$ during the Southern hemispheric biomass burning season in 2003, Atmos. Chem. Phys., 7, 5861-5872, doi:10.5194/acp-7-5861-2007, 2007.

von Clarmann, T., Stiller, G., Grabowski, U., Eckert, E., and Orphal, J.: Technical Note: Trend estimation from irregularly sampled, correlated data, Atmos. Chem. Phys., 10, 6737-6747, doi:10.5194/acp-10-6737-2010, 2010.

Watts, S. F.: The mass budgets of carbonyl sulfide, dimethyl sulfide, carbon disulfide and hydrogen sulfide, Atmos. Environ., 34, 761779, 2000.

$\mathrm{Xu}, \mathrm{X}$., Bingemer, H. G., and Schmidt, U.: The flux of carbonyl sulfide and carbon disulfide between the atmosphere and a spruce forest, Atmos. Chem. Phys., 2, 171-181, doi:10.5194/acp-2-1712002, 2002.

Yokelson, R. J., Bertschi, I. T., Christian, T. J., Hobbs, P. V., Ward, D. E., and Hao W. M.: Trace gas measurements in nascent, aged, and cloud-processed smoke from African savanna fires by airborne Fourier transform infrared spectroscopy (AFTIR), J. Geophys. Res., 108, 8478, doi:10.1029/2002JD002322, 2003.

Yokelson, R. J., Christian, T. J., Karl, T. G., and Guenther, A.: The tropical forest and fire emissions experiment: laboratory fire measurements and synthesis of campaign data, Atmos. Chem. Phys., 8, 3509-3527, doi:10.5194/acp-8-3509-2008, 2008. 